\title{
Reactive organic carbon emissions from volatile chemical products
}

\author{
Karl M. Seltzer ${ }^{1}$, Elyse Pennington ${ }^{2,3}$, Venkatesh Rao ${ }^{4}$, Benjamin N. Murphy ${ }^{5}$, Madeleine Strum ${ }^{4}$, Kristin K. Isaacs ${ }^{5}$, \\ and Havala O. T. Pye ${ }^{5}$ \\ ${ }^{1}$ Oak Ridge Institute for Science and Education Postdoctoral Fellow in the Office of Research and Development, \\ U.S. Environmental Protection Agency, Research Triangle Park, NC 27711, USA \\ ${ }^{2}$ Oak Ridge Institute for Science and Education Fellow in the Office of Research and Development, U.S. Environmental \\ Protection Agency, Research Triangle Park, NC 27711, USA \\ ${ }^{3}$ California Institute of Technology, Pasadena, CA 91125, USA \\ ${ }^{4}$ Office of Air and Radiation, U.S. Environmental Protection Agency, Research Triangle Park, NC 27711, USA \\ ${ }^{5}$ Office of Research and Development, U.S. Environmental Protection Agency, Research Triangle Park, NC 27711, USA
}

Correspondence: Havala Pye (pye.havala@epa.gov)

Received: 26 October 2020 - Discussion started: 9 November 2020

Revised: 8 February 2021 - Accepted: 9 February 2021 - Published: 31 March 2021

\begin{abstract}
Volatile chemical products (VCPs) are an increasingly important source of anthropogenic reactive organic carbon (ROC) emissions. Among these sources are everyday items, such as personal care products, general cleaners, architectural coatings, pesticides, adhesives, and printing inks. Here, we develop VCPy, a new framework to model organic emissions from VCPs throughout the United States, including spatial allocation to regional and local scales. Evaporation of a species from a VCP mixture in the VCPy framework is a function of the compound-specific physiochemical properties that govern volatilization and the timescale relevant for product evaporation. We introduce two terms to describe these processes: evaporation timescale and use timescale. Using this framework, predicted national per capita organic emissions from VCPs are $9.5 \mathrm{~kg}$ per person per year $(6.4 \mathrm{kgC}$ per person per year) for 2016, which translates to $3.05 \mathrm{Tg}$ (2.06 TgC), making VCPs a dominant source of anthropogenic organic emissions in the United States. Uncertainty associated with this framework and sensitivity to select parameters were characterized through Monte Carlo analysis, resulting in a $95 \%$ confidence interval of national VCP emissions for 2016 of $2.61-3.53 \mathrm{Tg}(1.76-2.38 \mathrm{TgC})$. This nationwide total is broadly consistent with the U.S. EPA's 2017 National Emission Inventory (NEI); however, countylevel and categorical estimates can differ substantially from NEI values. VCPy predicts higher VCP emissions than the
\end{abstract}

NEI for approximately half of all counties, with $5 \%$ of all counties having greater than $55 \%$ higher emissions. Categorically, application of the VCPy framework yields higher emissions for personal care products $(150 \%)$ and paints and coatings $(25 \%)$ when compared to the NEI, whereas pesticides $(-54 \%)$ and printing inks $(-13 \%)$ feature lower emissions. An observational evaluation indicates emissions of key species from VCPs are reproduced with high fidelity using the VCPy framework (normalized mean bias of $-13 \%$ with $r=0.95$ ). Sector-wide, the effective secondary organic aerosol yield and maximum incremental reactivity of VCPs are $5.3 \%$ by mass and $1.58 \mathrm{~g} \mathrm{O}_{3} \mathrm{~g}^{-1}$, respectively, indicating VCPs are an important, and likely to date underrepresented, source of secondary pollution in urban environments.

\section{Introduction}

Reactive organic carbon (ROC), which includes both nonmethane organic gases and organic aerosol (OA), is central to atmospheric oxidant levels and modulates the concentration of all reactive species (Heald and Kroll, 2020; Safieddine et al., 2017). Gas-phase ROC features both biogenic and anthropogenic sources and, following oxidation, can lead to the formation of tropospheric ozone $\left(\mathrm{O}_{3}\right)$ and secondary organic aerosol (SOA). Organic aerosol is often the dominant 
component of total fine particulate matter $\left(\mathrm{PM}_{2.5}\right)$ throughout the world (Jimenez et al., 2009; Zhang et al., 2007), and SOA is often the dominant component of OA in both urban and rural settings (Jimenez et al., 2009; Volkamer et al., 2006; Williams et al., 2010; Xu et al., 2015). Since ozone and $\mathrm{PM}_{2.5}$ are both associated with impacts on human health and welfare (U.S. Environmental Protection Agency, 2019a, 2020) that are global in nature (Burnett et al., 2018; Mills et al., 2018) and persist at low concentrations (Di et al., 2017; Kazemiparkouhi et al., 2020), accurately understanding the sources, magnitude, and speciation of organic emissions is critical.

Historically, the leading source of anthropogenic organic emissions in the United States has been motor vehicles (Khare and Gentner, 2018; McDonald et al., 2013; Pollack et al., 2013). However, successful emission reduction strategies implemented over several decades have dramatically reduced mobile emissions (Bishop and Stedman, 2008; Khare and Gentner, 2018; McDonald et al., 2013), resulting in substantial declines in both ambient gas-phase non-methane volatile organic compounds (NMVOCs) and OA concentrations (Gentner et al., 2017; McDonald et al., 2015; Pollack et al., 2013; Warneke et al., 2012). Due to these changes, volatile chemical products (VCPs) are now viewed as the foremost source of anthropogenic organic emissions (Khare and Gentner, 2018; McDonald et al., 2018). The U.S. EPA has long accounted for VCPs in the National Emissions Inventory (NEI) as the "solvent sector". In 1990, the mobile and VCP sectors were the two highest emitters of volatile organic compounds (VOCs; a regulatory-defined collection of organic species that excludes certain compounds, such as acetone) at the national level. Mobile and VCP sources emitted 7.2 and 5.0 Tg of VOCs, respectively (U.S. Environmental Protection Agency, 1995). By 2017, EPA estimates of VOC emissions from both the mobile and VCP sectors each dropped to $2.7 \mathrm{Tg}$ (U.S. Environmental Protection Agency, 2020). For VCPs, factors driving the emissions decrease over this period include, but are not limited to, reformulation of consumer products (Ozone Transport Commission, 2016) and implementation of National Emissions Standards for Hazardous Air Pollutants regulations for industrial processes (Strum and Scheffe, 2016). Potentially complicating the trend and assessment of relative roles of different sectors, new inventory methods have suggested that VCP emissions in the NEI could be biased low by a factor of 2-3 (McDonald et al., 2018).

The decades-long increasing relative contribution of VCPs to total anthropogenic organic emissions could have several important implications for modeling and improving air quality. First, modeling studies of SOA from anthropogenic VOCs have generally focused on combustion sources (Hodzic et al., 2010; Jathar et al., 2017; Murphy et al., 2017), which are typically rich in aromatics and alkanes (Gentner et al., 2012; Lu et al., 2018). In contrast, emissions from VCPs occur through evaporation and contain large fractions of oxygenated species (e.g., glycol ethers, siloxanes), many of which feature uncertain SOA yields (McDonald et al., 2018). Second, adequate chemical mechanism surrogates for species common in VCPs (e.g., siloxanes) are lacking (Qin et al., 2020). As VCPs and their components could have significant SOA potential (Li et al., 2018; Shah et al., 2020), revisiting VCP emissions mapping to chemical mechanisms could help reduce modeled bias, which has historically been difficult to resolve (Baker et al., 2015; Ensberg et al., 2014; Lu et al., 2020; Woody et al., 2016). Third, VCPs feature substantial quantities of intermediate-volatility organic carbon (IVOC) compounds (CARB, 2019), and better representing their source strength could help resolve the high IVOC concentrations observed in urban atmospheres (Lu et al., 2020; Zhao et al., 2014). Fourth, if the VCP sector is systematically biased low in the NEI or select urban areas, there could be implications for ozone pollution (Zhu et al., 2019). Finally, reducing organic emissions from VCPs has traditionally been viewed through the lens of minimizing near-field chemical exposure (Isaacs et al., 2014) or mitigating ozone pollution (Ozone Transport Commission, 2018), both of which can be accomplished through product reformulation. For example, reducing the magnitude of regulatory VOC emissions from VCPs can be accomplished by reformulating a product with lower-volatility ingredients that are less likely to evaporate (Ozone Transport Commission, 2016). However, if these lower-volatility replacement ingredients eventually evaporate on atmospherically relevant timescales, they could be efficient SOA precursors ( $\mathrm{Li}$ et al., 2018).

Given these implications, the need to understand and resolve differences among inventories becomes increasingly important. Here, we develop VCPy, a new framework to model organic emissions from VCPs throughout the United States, including spatial allocation to the county-level. In this framework, fate and transport assumptions regarding evaporation of a species in a product into ambient air are a function of the compound-specific physiochemical properties that govern volatilization and the timescale available for a product to evaporate. We introduce two terms to describe these processes: evaporation timescale and use timescale. Since product ingredients are considered individually, determination of emission composition is explicit. This approach also enables quantification of emission volatility distributions and the abundance of different compound classes. In addition, we test the sensitivity of predicted emission factors to uncertain parameters, such as evaporation timescale and use timescale, through Monte Carlo analysis, evaluate the VCPy inventory using published emission ratios, and estimate the effective SOA and ozone formation potential of both the complete sector and individual product use categories. 


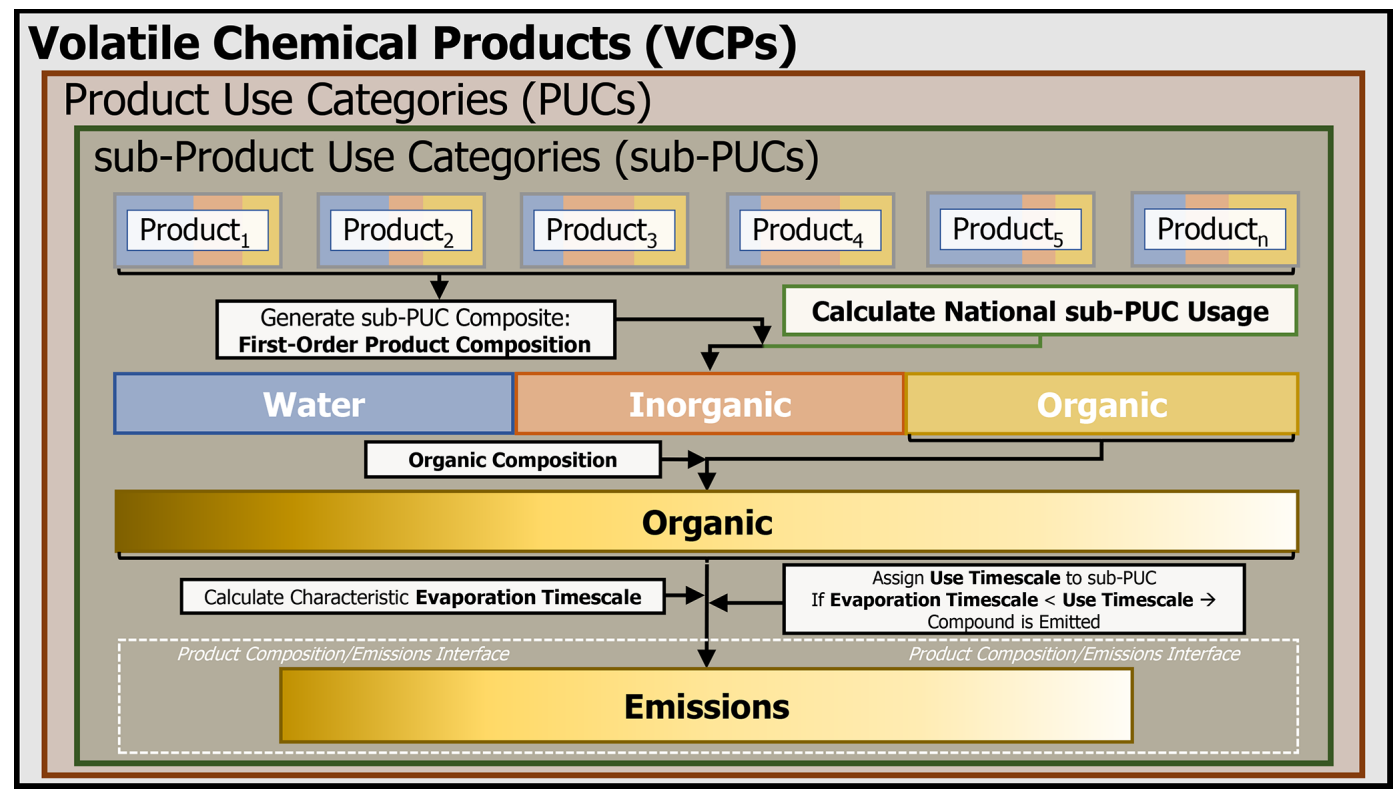

Figure 1. Conceptual overview of the VCPy framework. Note that PUC stands for product use category.

\section{Methods}

\subsection{VCPy: a framework for estimating reactive organic carbon emissions from volatile chemical products}

The VCPy framework is based on the principle that the magnitude and speciation of organic emissions from VCPs are directly related to (1) the mass of chemical products used, (2) the composition of these products, (3) the physiochemical properties of their constituents that govern volatilization, and (4) the timescale available for these constituents to evaporate (Fig. 1). Since the VCP sector includes residential, commercial, institutional, and industrial sources, a consistent stream of data sources for all product categories is difficult. As such, this work implements a hybridized methodology that utilizes the best features of prior emission inventory methods, while introducing new methods to make improvements where necessary. The result produces national-level per capita emission factors for all product categories in the VCP sector that can be further tailored for regional or localized analysis. The per capita basis is useful for comparison across frameworks and over time, but emissions can be recast in other units as needed. Briefly, survey data are used to generate a first-order product composition profile for a composite of product types, which quantifies the fraction of organic, inorganic, and water components. The organic component is further divided into individual species (e.g., ethanol, isobutane, isopropyl alcohol). A variety of data sources are used to estimate the national-level product usage, and each composite is assigned a use timescale, reflecting the elapsed time between use and any explicit removal process. Finally, the characteristic evaporation timescale of each organic component is calculated us- ing quantitative structure-activity relationship (QSAR) modeled physiochemical properties and compared to the assigned use timescale. If the characteristic evaporation timescale of the organic component is less than the assigned use timescale of the composite, it is assumed that the compound is emitted. If not, the compound is retained in the product or other condensed phase (e.g., water) and permanently sequestered.

\subsubsection{Product use categories (PUCs) and sub-product use categories (sub-PUCs)}

VCPy disaggregates the VCP sector into several components called product use categories (PUCs). An individual PUC is not exclusively used in a singular setting (e.g., residential vs. commercial), and examples include personal care products, cleaning products, and paints and coatings. PUCs are further divided into sub-PUCs, which are composites of individual product types featuring similar use patterns. In addition to permitting tailored fate and transport assumptions, similar hierarchical product schema are also useful for models estimating near-field exposure to chemicals through routes such as dermal contact and indoor inhalation (Isaacs et al., 2020). As an example, there are two sub-PUCs allocated to the personal care product PUC: short-use products and daily use products. These two sub-PUCs are differentiated by the length of use prior to removal (i.e., the use timescale). The mass of chemical products used and subsequent organic emission factors, which are the main output from VCPy, are calculated at the sub-PUC level (Fig. 1). Currently, there are 10 PUCs and 16 sub-PUCs implemented in VCPy (Table 1). 
Table 1. Description of all PUCs and sub-PUCs currently implemented in VCPy, their estimated mass usage for 2016, and product examples of each. See Table $\mathrm{S} 2$ for a derivation of all product usage estimates.

\begin{tabular}{|c|c|c|c|}
\hline $\begin{array}{l}\text { Product use } \\
\text { categories } \\
\text { (PUCs) }\end{array}$ & $\begin{array}{l}\text { Sub-product use } \\
\text { categories } \\
\text { (sub-PUCs) }\end{array}$ & $\begin{array}{r}2016 \text { annual usage } \\
\text { [kg per person } \\
\text { per year }]\end{array}$ & Product examples \\
\hline \multirow[t]{2}{*}{ Cleaning products } & Detergents and soaps & 40.58 & Soaps, detergents, metal cleaners, scouring cleaners \\
\hline & General cleaners & 28.47 & $\begin{array}{l}\text { Disinfectants, air fresheners, glass and bathroom cleaners, } \\
\text { windshield washer fluid, hand sanitizer, automotive and } \\
\text { floor polishes, bleaches, surfactants }\end{array}$ \\
\hline \multirow[t]{2}{*}{$\begin{array}{l}\text { Personal care } \\
\text { products }\end{array}$} & Daily use products & 8.83 & $\begin{array}{l}\text { Hair products, perfumes, colognes, cleansing and moisturizing creams, } \\
\text { sunscreens, hand and body lotion and oils, cosmetics, deodorants }\end{array}$ \\
\hline & Short-use products & 3.16 & $\begin{array}{l}\text { Shampoo, conditioners, shaving cream, aftershave, } \\
\text { mouthwashes, toothpaste }\end{array}$ \\
\hline $\begin{array}{l}\text { Adhesives and } \\
\text { sealants }\end{array}$ & Adhesives and sealants & 15.23 & $\begin{array}{l}\text { Glues and adhesives, epoxy adhesives, other adhesives, structural } \\
\text { and nonstructural caulking compounds and sealants }\end{array}$ \\
\hline \multirow{4}{*}{$\begin{array}{l}\text { Paints and } \\
\text { coatings }\end{array}$} & Architectural coatings & 13.27 & Exterior/interior flat/gloss paints, primers, sealers, lacquers \\
\hline & Aerosol coatings & 0.39 & Paint concentrates produced for aerosol containers \\
\hline & Allied paint products & 1.26 & Thinners, strippers, cleaners, paint/varnish removers \\
\hline & Industrial coatings & 7.42 & $\begin{array}{l}\text { Automotive, appliance, furniture, paper, electrical insulating, marine, } \\
\text { maintenance, and traffic marking finishes and paints }\end{array}$ \\
\hline Printing inks & Printing inks & 3.20 & $\begin{array}{l}\text { Letterpress, lithographic, gravure, flexographic, } \\
\text { non-impact/digital inks }\end{array}$ \\
\hline \multirow[t]{2}{*}{$\begin{array}{l}\text { Pesticides and } \\
\text { FIFRA products }\end{array}$} & FIFRA pesticides & 1.46 & $\begin{array}{l}\text { Lawn and garden pesticides and chemicals, household and } \\
\text { institutional pesticides and chemicals }\end{array}$ \\
\hline & Agricultural pesticides & 10.32 & Agricultural and commercial pesticides and other organic chemicals \\
\hline Dry cleaning & Dry cleaning & 0.03 & Dry cleaning fluids \\
\hline Oil and gas & Oil and gas & 1.32 & Cleaners, deicers \\
\hline Misc. products & Misc. products & 0.18 & Pens, markers, arts and crafts, dyes \\
\hline Fuels and lighter & Fuels and lighter & 2.80 & Lighter fluid, fire starter, other fuels \\
\hline
\end{tabular}

\subsubsection{National-level product usage}

To estimate VCP product use, some prior work has used national economic statistics, such as market sales or shipment values (e.g., U.S. Environmental Protection Agency, 2020; McDonald et al., 2018). Others have incorporated product usage statistics based on consumer habits and practices (e.g., Isaacs et al., 2014; Qin et al., 2020), but these statistics are generally unavailable for commercial and industrial chemical usage, which limits their application. To better ensure the capture of all chemical product usage, including usage in residential, commercial, institutional, and industrial settings, where possible national economic statistics are utilized (Table S1 in the Supplement).

Product usage from 12 sub-PUCs is estimated using national-level shipment statistics, commodity prices, and producer price indices. National-level economic statistics are retrieved from the U.S. Census Bureau's Annual Sur- vey of Manufactures (ASM; U.S. Census Bureau, 2016a), which provides annual statistical estimates for all manufacturing establishments. Values are available for all six-digit North American Industry Classification System (NAICS) codes, provided as product shipment values $\left(\mathrm{USD} \mathrm{yr}^{-1}\right)$, and are reported with associated relative standard errors (generally $<5 \%)$. To translate shipment values $\left(\mathrm{USD} \mathrm{yr}^{-1}\right)$ to usage $\left(\mathrm{kg} \mathrm{yr}^{-1}\right)$, we use commodity prices (USD kg ${ }^{-1}$ ) from the U.S. Department of Transportation's 2012 Commodity Flow Survey (U.S. Department of Transportation, 2015). An exception is for all paint and coating sub-PUCs. Commodity prices for these sub-PUCs are taken from the U.S. Census Bureau's Paint and Allied Products Survey (U.S. Census Bureau, 2011a) and are representative of 2010. To translate these commodity prices, which are from 2010 and 2012, to values reflective of 2016, we use producer price indices reported by the Federal Reserve Bank of St. Louis (U.S. Bureau of Labor Statistics, 2020). Commodity price indices 
from the Federal Reserve Bank are updated for all NAICS manufacturing codes monthly, which we average to create annual price indices (Table S2). An implicit assumption in this methodology is that manufacturing and product usage are, on average, annually balanced.

We preferentially utilize product usage numbers derived from the above methodology, when possible, as all data sources have the following characteristics: (1) they are nationally derived and therefore less influenced by regional differences in manufacturing and formulation, and (2) all datasets are freely available to the public. However, due to data limitations, product usage for four sub-PUCs is estimated using other sources. The dry cleaning and oil and gas product usage estimates are derived from the national-level solvent mass usage reported by an industry study (The Freedonia Group, 2016). The miscellaneous products and fuels and lighter product usage estimates are derived from reported sales data, specific to California, from the California Air Resources Board's 2015 Consumer and Commercial Products Survey Data (CARB, 2019). These sales numbers are scaled upwards to a national-level by assuming equivalent per capita product usage.

\subsubsection{First-order and organic product composition}

Each sub-PUC features two composite profiles. The initial composite is the first-order product composition profile, which disaggregates the total mass of each sub-PUC into its water, inorganic, and organic fractions (Table 2). The organic component is further decomposed into non-evaporative and evaporative organics. The quantification and accounting of evaporative organics in this framework are necessary as CARB's organic profiles are processed to exclude organics that are not anticipated to evaporate on atmospherically relevant timescales. For 10 sub-PUCs, the first-order product composition profile uses data from the California Air Resources Board's 2015 Consumer and Commercial Products Survey (CARB, 2019). Various product types are sorted into each sub-PUC and the first-order product composition profiles are calculated on a weighted basis using the reported sales from manufacturers and formulators in California. Due to omissions stemming from confidentiality concerns, not all sales and composition data from the survey are available. We utilize the publicly available portions of the data, which constitutes most of the survey and includes over 330 product types. For example, 126 product types and 20 product types were sorted into the general cleaners and adhesives and sealants (Table S3) sub-PUCs, respectively.

For architectural coatings, industrial coatings, and printing inks, the first-order product composition profile is derived from data in the California Air Resources Board's 2005 Architectural Coatings Survey (CARB, 2007). The Architectural Coatings sub-PUC uses data from all profiles in the survey, which is dominated by flat paint, non-flat paints, and primers. Industrial coatings and printing inks use the first- order product composition profiles of industrial maintenance coatings and graphic arts coatings, respectively. The firstorder product composition profile for aerosol coatings uses data from the California Air Resources Board's 2010 Aerosol Coatings Survey (CARB, 2012), which includes more than 20 aerosolized product types. Only the evaporative organic composition of aerosol coating products was reported, so the remaining mass was evenly split between water and inorganics. For dry cleaning and oil and gas, as the product usage for these sub-PUCs was derived from the organic functional solvent mass usage, it is assumed that this mass is entirely evaporative organics.

The second composite is the organic composition profile. Again, the California Air Resources Board's 2015 Consumer and Commercial Products Survey (CARB, 2019) was used to derive a composite of product types for 10 sub-PUCs (Table S4). These product types are then mapped to an associated organic profile (CARB, 2018; see Table S3) and weighted based on their evaporative organic contributions to the total sub-PUC. For architectural coatings, a $94 \%$ waterbased and $6 \%$ solvent-based paint (CARB, 2014) composite is generated. Aerosol coatings are calculated on a weighted basis using the potentially evaporative organic contributions reported by CARB's 2010 Aerosol Coatings Survey (CARB, 2012). The organic composition profiles for industrial coatings, printing inks, and dry cleaning all utilize profiles $(3149,2570,2422$, respectively) from EPA's SPECIATEv5.0 database (EPA, 2019b). Approximately $65 \%$ of the solvents used in the oil and gas sector are alcohols, and the remainder are a broad range of hydrocarbons (The Freedonia Group, 2016). Since detailed composition data for oil and gas solvents are sparse, all oil and gas alcohols are assumed to be methanol, as it is widely used in and emitted from oil and gas operations (Lyman et al., 2018; Stringfellow et al., 2017; Mansfield et al., 2018). The remaining $35 \%$ is allocated to naphtha, a blend of hydrocarbon solvents.

Several components within CARB profiles are lumped categories or complex mixtures. This includes naphtha, mineral spirits, distillates, Stoddard solvent, fragrances, volatile methyl siloxanes, and a series of architectural coating and consumer product "bins." All naphtha, mineral spirits, distillates, and Stoddard solvent occurrences in individual profiles are treated as a single-mineral spirit profile (Carter, 2015). Volatile methyl siloxanes include several compounds (e.g., $\mathrm{D}_{4}, \mathrm{D}_{5}, \mathrm{D}_{6}$ ), all of which are emitted in varying proportions (Janechek et al., 2017). Here, the lumped volatile methyl siloxane identity is preserved but the physiochemical properties of decamethylcyclopentasiloxane is applied to the surrogate. Fragrances are a diverse mixture of organic compounds that include many terpenes and alkenes (Nazaroff and Weschler, 2004; Sarwar et al., 2004; Singer et al., 2006b). However, since the proportion of these constituents are unknown, all fragrances are physically treated as d-limonene since it is the most prevalent terpene emitted from fragranced products (Sarwar et al., 2004; Singer et al., 2006b). Finally, 
Table 2. First-order product composition profiles and evaporative organics proportion for all sub-PUCs.

\begin{tabular}{|c|c|c|c|c|c|}
\hline $\begin{array}{l}\text { Product use categories } \\
\text { (PUCs) }\end{array}$ & $\begin{array}{l}\text { Sub-product use categories } \\
\text { (sub-PUCs) }\end{array}$ & $\begin{array}{r}\text { Water } \\
{[\%]}\end{array}$ & $\begin{array}{r}\text { Inorganic } \\
{[\%]}\end{array}$ & $\begin{array}{r}\text { Non-evaporative } \\
\text { organics }^{\mathrm{a}} \\
{[\%]}\end{array}$ & $\begin{array}{r}\text { Evaporative } \\
\text { organics }^{\mathrm{a}} \\
{[\%]}\end{array}$ \\
\hline \multirow[t]{2}{*}{ Cleaning products } & Detergents and soaps ${ }^{b}$ & 67.8 & 13.9 & 15.4 & 2.9 \\
\hline & General cleaners ${ }^{b}$ & 73.3 & 8.6 & 11.1 & 6.9 \\
\hline \multirow[t]{2}{*}{ Personal care products } & Daily use products ${ }^{\mathrm{b}}$ & 48.8 & 10.7 & 16.9 & 23.7 \\
\hline & Short-use products ${ }^{b}$ & 72.2 & 5.8 & 17.7 & 4.3 \\
\hline Adhesives and sealants & Adhesives and sealants $\mathrm{b}$ & 12.8 & 53.2 & 29.0 & 5.0 \\
\hline \multirow[t]{4}{*}{ Paints and coatings } & Architectural coatings $^{\mathrm{c}}$ & 45.5 & 49.6 & 0.0 & 5.0 \\
\hline & Aerosol coatings ${ }^{\mathrm{d}}$ & 12.7 & 12.7 & 0.0 & 74.7 \\
\hline & Allied paint products ${ }^{b}$ & 5.1 & 3.5 & 0.6 & 90.8 \\
\hline & Industrial coatings ${ }^{\mathrm{e}}$ & 15.0 & 70.0 & 0.0 & 14.0 \\
\hline Printing inks & Printing inks ${ }^{f}$ & 8.0 & 67.0 & 0.0 & 25.0 \\
\hline \multirow[t]{2}{*}{ Pesticides and FIFRA products } & FIFRA pesticides ${ }^{b}$ & 74.8 & 4.9 & 15.1 & 5.1 \\
\hline & Agricultural pesticides ${ }^{b}$ & 74.8 & 4.9 & 15.1 & 5.1 \\
\hline Dry cleaning & Dry cleaning $g$ & 0.0 & 0.0 & 0.0 & 100 \\
\hline Oil and gas & Oil and gasg & 0.0 & 0.0 & 0.0 & 100 \\
\hline Misc. products & Misc. products ${ }^{\mathrm{b}}$ & 27.1 & 14.6 & 48.8 & 9.5 \\
\hline Fuels and lighter & Fuels and lighter ${ }^{b}$ & 0.0 & 92.9 & 0.0 & 7.1 \\
\hline \multicolumn{6}{|c|}{$\begin{array}{l}\text { a "Non-evaporative organics" and "evaporative organics" sum to total product organics. "Evaporative organics" represent the potentially evaporative organic } \\
\text { fraction of the total product and excludes assumed "non-evaporative" (i.e., assumed non-volatile) organics, which are not included in the California Air }\end{array}$} \\
\hline \multicolumn{6}{|c|}{$\begin{array}{l}\text { Resource Board's organic profiles. }{ }^{\mathrm{b}} \text { California Air Resources Board } 2015 \text { Consumer and Commercial Products Survey Data (CARB, 2019). }{ }^{c} \text { California Air } \\
\text { Resources Board } 2005 \text { Architectural Coatings Survey (CARB, 2007). VOC + exempt is used for both organic and evaporative organics. Non-evaporative } \\
\text { organic proportions not provided. Sales proportions of water-based vs. solvent-based architectural coatings based on California Air Resource Board } 2014 \\
\text { Architectural Coatings Survey (CARB, 2014). }{ }^{\mathrm{d}} \text { California Air Resources Board } 2010 \text { Aerosol Coatings Survey (CARB, 2012); only evaporative organics is } \\
\text { provided; the remainder }(\sim 25 \%) \text { is split evenly between water and inorganics. }{ }^{\mathrm{e}} \text { Industrial maintenance composition data from California Air Resources }\end{array}$} \\
\hline
\end{tabular}

for the architectural coating and consumer product "bins," we use the representative chemical compositions derived by Carter, 2015.

\subsubsection{Controls}

There are two methods for controlling organic emissions from VCPs. The first method is through product reformulation, which would occur prior to product usage. Strategies that fit this definition include switching from a hydrocarbon solvent-based ingredient to one that is water-based, replacing an organic component with a non-organic component, and reformulating a product with lower-volatility ingredients that are less likely to evaporate (Ozone Transport Commission, 2016). VCP emissions that stem from residential, commercial, and institutional settings rely on these pre-use controls to reduce emissions. Regulators often set VOC content limits for chemical products (e.g., national standards: Section 183(e) of the Clean Air Act; 40 CFR 59), with California (e.g., CARB - Title 17 CCR) typically setting some of the most stringent limits in the country (Ozone Transport Commission, 2016). As the first-order and organic composition profiles utilized here are almost exclusively derived from product composition data, pre-use controls are implicitly represented. In fact, since the product composition data is from manufacturers and formulators in California, where product VOC content limits are typically more stringent than national regulations, applying these profiles nationally likely results in conservative assumptions.

The second pathway of controlling organic emissions from VCPs is through post-use controls. Strategies that fit this definition include add-on controls, manufacturing process modifications, and disposal techniques. Add-on control strategies and manufacturing process modifications are limited to industrial and commercial emission sources, such as industrial coating (U.S. EPA, 2007, 2008) and printing ink (U.S. EPA, 2006a, b) facilities. Since adoption of these technologies vary widely in space and time, assigning post-use controls via these strategies is not considered here. As several of these industrial sources (e.g., coatings, printing inks, dry 
cleaning) feature controls, as required by Section 112 of the Clean Air Act (40 CFR 63), this assumption could lead to localized high bias and will be refined in future work. Here, we only consider post-use controls through disposal techniques for the oil and gas and fuels and lighter sub-PUCs. For oil and gas, we assume that the solvents used in these processes become entrained in the produced water at these sites. Since produced water is largely $(\sim 89 \%-98 \%)$ reinjected for enhanced oil and gas recovery or disposal (Lyman et al., 2018; Liden et al., 2018), we apply a post-use control efficiency of $94 \%$ (i.e., average of reported reinjection rates) to this subPUC. However, it should be noted that reinjection frequency and solvent usage can vary regionally. For fuels and lighters, we assume $90 \%$ of the organics are destroyed through combustion upon use (CARB, 2019).

\subsubsection{Evaporation timescale and use timescale}

Fate and transport in the VCPy framework is a function of the predicted compound-specific evaporation timescale and the assigned use timescale of each sub-PUC. It should be noted that this methodology explicitly results in the organic speciation of emissions differing from the organic composition of products from which they volatilize. For example, the composition of organics within a product may differ from the speciation of emitted organics if the product contains low-volatility compounds that do not evaporate on relevant timescales.

The evaporation timescale is the compound-specific (i.e., independent of the sub-PUC of interest) characteristic timescale of emission from a surface layer and is calculated using previously published methods (Khare and Gentner, 2018; Weschler and Nazaroff, 2008). This timescale is defined as a relationship between the mass of a compound applied and the rate of its emission, which can be expressed by

Evaporation timescale $[\mathrm{h}]=\frac{M_{\text {applied }}}{R_{\text {emission }}}=\frac{K_{\mathrm{OA}} \cdot d}{v_{\mathrm{e}}}$,

where $K_{\mathrm{OA}}$ is the octanol-air partitioning coefficient of the compound, $d[\mathrm{~m}]$ is the assumed depth of the applied product layer, and $v_{\mathrm{e}}\left[\mathrm{mh}^{-1}\right]$ is the mass transfer coefficient of the compound from the surface layer into the bulk air, which is a function of aerodynamic and boundary layer resistances. Median values for $d[0.1 \mathrm{~mm}]$ and $v_{\mathrm{e}}\left[30 \mathrm{mh}^{-1}\right]$ from Khare and Gentner (2018) are selected here. It should be noted that $v_{\mathrm{e}}$ can vary substantially based on outdoor vs. indoor atmospheric conditions, and future work will incorporate a two-box model to better account for such differences. A compound's $K_{\mathrm{OA}}$ is the ratio of an organic chemical's concentration in octanol to the organic chemical's concentration in air at equilibrium. It is often used to quantify the partitioning behavior of an organic compound between air and a matrix. As experimental values of $K_{\mathrm{OA}}$ are sparse, modeled estimates from the quantitative structure-activity relationship (QSAR) model OPERA (Mansouri et al., 2018) are used here. All physiochemical properties, including OPERA results, are retrieved from the U.S. EPA's CompTox Chemistry Dashboard (https://comptox.epa.gov/dashboard, last access: 31 August 2020).

Use timescale is the timescale available for a sub-PUC to evaporate and is based on the length of its direct use phase (i.e., the elapsed time between application and any explicit removal process). As this value is subjective, broad values are applied to each sub-PUC (Table S5). For example, it is assumed that all products used in the bath and shower are quickly sequestered and washed down the drain, thus largely unavailable for emission (Shin et al., 2015). As such, short-use personal care products are assigned a "minutes" use timescale. In contrast, it is also assumed that each person bathes once a day, and associated daily use personal care products are therefore assigned a "days" use timescale.

Emissions are determined by comparing the calculated evaporation timescale for each component with the assigned use timescale for the sub-PUC. If the use timescale for the sub-PUC is greater than the evaporation timescale for a compound, the compound is emitted. Else, the compound is retained in the product or other condensed phase and permanently sequestered. Overall, organic emissions (E) for the complete sector are calculated as a summation over all organic compounds, $i$, and sub-PUCs, $j$, as follows:

$$
E=\sum_{i, j}\left\{\begin{array}{l}
0 \\
\text { if use timescale } \\
j \\
U_{j} \cdot f_{\mathrm{E}_{j}} \cdot f_{\mathrm{S}_{i, j}} \cdot\left(1-f_{\mathrm{C}_{j}}\right) \\
\text { if use timescale } \text { timation }_{j} \geq \text { evaporation timescale }_{i}
\end{array},\right.
$$

where $U$ is the product usage (Table 1$), f_{\mathrm{E}}$ is the evaporative organic fraction (Table 2), $f_{\mathrm{S}}$ is the fraction of an organic compound in the evaporative organics portion of a sub-PUC (Table S4), and $f_{\mathrm{C}}$ is the fraction of emissions that feature post-use controls on a mass basis. Application of Eq. (2) determines the difference between organic product composition and organic emissions speciation.

\subsection{Uncertainty analysis}

The sensitivity of emission estimates to a variety of input variables are tested through a systematic Monte Carlo analysis. We perform 10000 simulations where product usage, evaporative organic proportions, variables associated with the characteristic evaporation timescale, the assigned use timescale, and post-use control assumptions are tested, both individually and collectively. For product usage, the primary sources of uncertainty are shipment values provided by the ASM, commodity prices, the balance of imports (including tourism) and exports, and unused product disposal. The ASM provides standard error estimates for most shipment values, which are typically less than $5 \%$. Uncertainty estimates are 
not provided for commodity prices, and national-level exports generally outweigh traditional imports for most subPUCs ( 2\%-15\%; U.S. Census Bureau, 2016), but there are also imports of personal care products through tourism. Therefore, we assume there is a $\pm 25 \%$ uncertainty $(95 \% \mathrm{CI})$ for all product usage estimates. CARB does not provide uncertainty estimates associated with the composition of product types or sales proportions. To account for these uncertainties, as well as the uncertainties associated with generating composites, we assume there is a $\pm 25 \%$ uncertainty (95\% CI) for all "evaporative organic" (Table 2) proportions. For the characteristic evaporation timescale, there are several layers of uncertainty. Application patterns vary by product type, which impacts assumptions regarding the depth of the chemical layer. In addition, indoor vs. outdoor product use and application of products to variable surface types (e.g., absorbing vs. non-absorbing) can impact mass transfer rates. As such, we apply broad uncertainties for variables associated with the characteristic evaporation timescale. We assume $d$ (i.e., the depth of the applied chemical layer) is lognormally distributed with a median value of $0.1 \mathrm{~mm}(95 \% \mathrm{CI} \sim[0.01-$ $1 \mathrm{~mm}]$ ), and $v_{\mathrm{e}}$ (i.e., the mass transfer coefficient) is normally distributed with a mean value of $30 \mathrm{mh}^{-1}(95 \% \mathrm{CI}=[10-$ $50 \mathrm{mh}^{-1}$ ]). Since use timescales are categorical (e.g., minutes, days, years), we apply uncertainty by assuming the $95 \% \mathrm{CI}$ of the assigned use timescale features a \pm 1 categorical uncertainty (e.g., mean: minutes; $95 \% \mathrm{CI}=$ [seconds hours]). Finally, for non-zero post-use controls, we assume $\mathrm{a} \pm 25 \%$ uncertainty $(95 \% \mathrm{CI})$ in the post-use control efficiency. It should be noted that additional avenues of uncertainty likely persist but are difficult to quantify and therefore not included here. For example, due to the scarcity of large-scale product surveys, many of the first-order product composition profiles (e.g., architectural coatings) and organic profiles (e.g., printing inks) used in this analysis are more than a decade old. As a result, the proportion of organics in these product types and their organic components (i.e., the mean values applied here) may have changed in the interim period. Furthermore, the uncertainty associated with the evaporative organic composition of individual product types is not known or provided by the source data.

\subsection{Spatial allocation of national-level emissions}

Emissions are calculated at the national-level and spatially allocated to the county-level using several proxies. A total of 10 sub-PUCs, including all cleaning products and personal care products, are allocated using population (Table S6; U.S. Census Bureau, 2020). Four sub-PUCs (industrial coatings, allied paint products, printing inks, dry cleaning), all typically industrial in nature, are allocated using county-level employment statistics from the U.S. Census Bureau's County Business Patterns (U.S. Census Bureau, 2018). The employment mapping scheme for these four sub-PUCs utilize the methods from the 2017 NEI (U.S. EPA, 2020). On occa- sion, data in the County Business Patterns (CBP) is withheld due to confidentiality concerns. In those instances, we take the midpoint of the range associated with each data suppression flag. For agricultural pesticides, emissions are allocated based on county-level agricultural pesticide use and again taken from the 2017 NEI (U.S. EPA, 2020). Oil and gas emissions are allocated using oil and gas well counts (U.S. EIA, 2019).

\subsection{Inventory evaluation}

Previously published emission ratios from the Los Angeles basin during the summer of 2010 (de Gouw et al., $2018,2017)$ are used to evaluate the VCPy emissions inventory (Table S7). Emissions ratios are generated by postprocessing observed concentrations of organic gases, typically normalized to carbon monoxide (CO) or acetylene, to a period of "no chemistry" (Borbon et al., 2013; de Gouw et al., 2005; Warneke et al., 2007). As the air parcel is not photochemically aged (i.e., "no chemistry"), it is an ideal tool for evaluating an emissions inventory. An important caveat is that this method assumes the species being used for normalization (e.g., CO) is accurately inventoried and measured.

Since the emission ratios are not specific to a sector and represent total emissions, all other sectors must be quantified and speciated. For this purpose, all non-VCP anthropogenic emissions from the 2017 NEI (U.S. EPA, 2020) are collected and speciated using EPA's SPECIATEv5.0 database (EPA, 2019b; Table S8). This includes all on road, non-road, nonpoint, and point sources. All VCP emissions from the 2017 NEI are also collected and speciated for supplementary evaluation. In addition, biogenic emissions of ethanol, methanol, and acetone for May and June 2016, as simulated by the Biogenic Emission Inventory System (Bash et al., 2016), were included to capture non-anthropogenic sources of these compounds. May and June were selected to coincide with the observational sampling months (de Gouw et al., 2018, 2017). As the observed emission ratios are specific to the Los Angeles basin, we derive all VCPy inventory emission ratios using data for Los Angeles County. Total CO emissions, including all on-road, non-road, nonpoint, and point sources, for Los Angeles County in 2017 are $\sim 320 \mathrm{Gg}$. While the observed and VCPy inventory emission ratios are separated by 6-7 years, the ambient non-methane hydrocarbon to $\mathrm{CO}$ concentration ratio in Los Angeles has been consistent for several decades, indicating changes in emission controls feature similar improvements for both pollutants over time (McDonald et al., 2013). In addition, the magnitude of observed emission ratios for a given region do not appreciably change over marginal time horizons (Warneke et al., 2007).

\subsection{Air quality impact potential}

Each organic compound is assigned a SOA yield and maximum incremental reactivity (MIR) to facilitate an approx- 
imation of the potential air quality impacts of VCPs. For SOA, a wide collection of published yields, including both chamber results and prediction tools, were utilized (Fig. S1 in the Supplement). These include (1) all linear alkanes use a quadratic polynomial fit to the volatility basis set (VBS) data from Presto et al. (2010) at $10 \mu \mathrm{g} \mathrm{m}^{-3}$; (2) all cyclic alkanes use linear alkane yields that are three carbons larger in size (Tkacik et al., 2012); (3) all branched alkanes use yields obtained from the Statistical Oxidation Model (SOM; Cappa and Wilson, 2012), as reported in McDonald et al. (2018); (4) benzene and xylenes use the average yields from $\mathrm{Ng}$ et al. (2007) under high- $\mathrm{NO}_{x}$ conditions; (5) toluene uses the average from $\mathrm{Ng}$ et al. (2007) under high- $\mathrm{NO}_{x}$ conditions and the VBS data from Hildebrant et al. (2009) at $10 \mu \mathrm{g} \mathrm{m}^{-3}$; (6) all alkenes use yields obtained from SOM, as reported in McDonald et al. (2018); (7) volatile methyl siloxanes use the two-product model parameters from Janecheck et al. (2019), which includes additional SOA yields from $\mathrm{Wu}$ and Johnson (2017), at $10 \mu \mathrm{g} \mathrm{m}^{-3}$; (8) all glycol ethers use chamber results and molecular structure relationships from $\mathrm{Li}$ and Cocker (2018) for reported and unreported glycol ethers, respectively; (9) benzyl alcohol uses the average of the lower-bound yields reported by Charan et al. (2020); (10) all remaining non-cyclic oxygenates, where available, use the arithmetic average of SOM results and a 1-D VBS approach, as reported by McDonald et al. (2018); (11) all remaining cyclic oxygenates, where available, use yields obtained from SOM, as reported by McDonald et al. (2018); (12) all halocarbons and compounds with less than five carbons are assigned a yield of zero; and (13) all remaining species are conservatively assigned a yield of zero if the effective saturation concentration (i.e., $\left.C^{*}=\left(P^{\text {vap }} \cdot \mathrm{MW}\right) /(R \cdot T)\right)$ is $\geq 3 \times 10^{6} \mu \mathrm{g} \mathrm{m} \mathrm{m}^{-3}$ and assigned the same yield as $n$-dodecane if the effective saturation concentration is $<3 \times 10^{6} \mu \mathrm{g} \mathrm{m}^{-3}$. The MIR of each compound, which measures the formation potential of ozone under various atmospheric conditions where ozone is sensitive to changes in organic compounds (Carter, 2010b), is calculated using the SAPRC-07 chemical mechanism (Carter, 2010a) and expressed as a mass of additional ozone formed per mass of organic emitted (Carter, 2010b).

\section{Results and discussion}

\subsection{National-level PUC and sub-PUC emissions}

National-level, per capita organic emissions from VCPs are $9.5 \mathrm{~kg}$ per person per year $(6.4 \mathrm{kgC}$ per person per year) for 2016 (Table 3), which translates to $3.05 \mathrm{Tg}(2.06 \mathrm{TgC})$. When filtered to remove regulatory exempt organics, total emissions from VCPs are 2.6 Tg of VOC. In comparison, the 2017 NEI reports a combined total of $2.6 \mathrm{Tg}$ of VOC emissions for on-road mobile, non-road mobile, and other mobile (i.e., aircraft, commercial marine vessels, and locomotives) sources. Therefore, when measured as VOC, the VCP sector

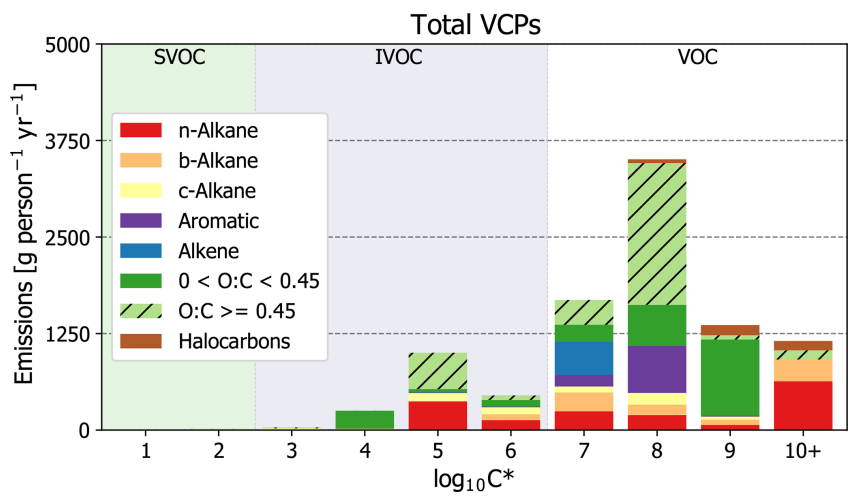

Figure 2. Sector-wide volatility distribution of emissions by compound class.

is equal in magnitude to the sum of all mobile sources nationally, which is broadly consistent with the national-level emissions estimate from the 2017 NEI. Categorically, emission factors are largest for paints and coatings, which total $3.1 \mathrm{~kg}$ per person per year $(2.2 \mathrm{kgC}$ per person per year) and are approximately $33 \%$ of the total sector (Table 3 ). The next largest PUCs are personal care products and cleaning products, which contribute $2.1 \mathrm{~kg}$ per person per year $(22 \%)$ and $2.0 \mathrm{~kg}$ per person per year $(21 \%)$, respectively. Printing inks, adhesives and sealants, and pesticides each account for $6 \%-$ $9 \%$ each, and the remaining PUCs contribute less than $2 \%$ in total.

For the complete sector (Fig. 2), the most abundantly emitted compound classes were oxygenated species (53\%), followed by alkanes (31\%; including straight-chained, branched, and cyclic), aromatics (8\%), alkenes (5\%), and halocarbons (3\%). Individually, organic emissions are dominated by ethanol (daily use products, general cleaners), acetone (paints and coatings, general cleaners), isopropyl alcohol (daily use products, general cleaners), toluene (paints and coatings, adhesives and sealants), $n$-tetradecane (printing inks), fragrances (daily use products, general cleaners), propane (aerosol coatings, industrial coatings), and volatile methyl siloxanes (daily use products, adhesives and sealants). Each of these species compose $>3 \%$ of total VCP organic emissions (see Table S9 for the top 200 most emitted compounds).

In terms of volatility classification (Donahue et al., 2012), as determined by the effective saturation concentration (i.e., $\mathrm{C}^{*}$ ), total emissions are predominately VOCs $\left(C^{*}>3 \times 10^{6} \mathrm{\mu g} \mathrm{m}^{-3}\right)$, but there are also considerable contributions from IVOCs $\left(3 \times 10^{2} \mu \mathrm{g} \mathrm{m}^{-3}<\right.$ $C^{*}<3 \times 10^{6} \mu \mathrm{g} \mathrm{m}^{-3}$; Figs. 2 and 3). IVOC emissions, which are efficient SOA precursors (Chan et al., 2009; Presto et al., 2010), are approximately $20 \%$ of total emissions. Of the $20 \%$ that are IVOCs, $52 \%$ are oxygenated compounds (e.g., Texanol ${ }^{\mathrm{TM}}$, propylene glycol, ethylene glycol, siloxanes, benzyl alcohol, and glycol ethers), $30 \%$ are $n$-alkanes, and the 
Table 3. National-level emissions, volatilization fraction, and proportion of all usage that is emitted for all sub-PUCs.

\begin{tabular}{|c|c|c|c|c|c|}
\hline \multirow{2}{*}{$\begin{array}{l}\text { Product use } \\
\text { categories } \\
\text { (PUCs) }\end{array}$} & \multirow{2}{*}{$\begin{array}{l}\text { Sub-product use } \\
\text { categories } \\
\text { (sub-PUCs) }\end{array}$} & \multicolumn{2}{|c|}{$\begin{array}{c}\text { ROC } \\
\text { emissions }\end{array}$} & \multirow{2}{*}{$\begin{array}{l}\text { Organic } \\
\text { volatilization } \\
\text { fraction }[\%]^{\mathrm{a}}\end{array}$} & \multirow{2}{*}{$\begin{array}{r}\text { Total product } \\
\text { emitted } \\
{[\%]}\end{array}$} \\
\hline & & $\begin{array}{l}\text { [kg per person } \\
\text { per year] }\end{array}$ & $\begin{array}{c}{[\mathrm{kgC} \text { per person }} \\
\text { per year }]\end{array}$ & & \\
\hline \multirow[t]{2}{*}{ Cleaning products } & Detergents and soaps & 0.12 & 0.06 & 1.6 & 0.3 \\
\hline & General cleaners & 1.85 & 1.25 & 36.0 & 6.5 \\
\hline \multirow[t]{2}{*}{ Personal care products } & Daily use products & 2.04 & 1.12 & 56.9 & 23.1 \\
\hline & Short-use products & 0.02 & 0.01 & 3.3 & 0.7 \\
\hline Adhesives and sealants & Adhesives and sealants & 0.76 & 0.56 & 14.7 & 5.0 \\
\hline \multirow[t]{4}{*}{ Paints and coatings } & Architectural coatings & 0.67 & 0.37 & $100^{\mathrm{b}}$ & 5.0 \\
\hline & Aerosol coatings & 0.29 & 0.22 & $100^{\mathrm{b}}$ & 74.7 \\
\hline & Allied paint products & 1.14 & 0.80 & 99.2 & 90.6 \\
\hline & Industrial coatings & 1.04 & 0.79 & $100^{\mathrm{b}}$ & 14.0 \\
\hline Printing inks & Printing inks & 0.80 & 0.65 & $100^{\mathrm{b}}$ & 25.0 \\
\hline \multirow{2}{*}{$\begin{array}{l}\text { Pesticides and FIFRA } \\
\text { products }\end{array}$} & FIFRA pesticides & 0.07 & 0.06 & 25.2 & 5.1 \\
\hline & Agricultural pesticides & 0.53 & 0.41 & 25.2 & 5.1 \\
\hline Dry cleaning & Dry cleaning & 0.01 & 0.01 & 34.5 & 34.5 \\
\hline Oil and gas & Oil and gas & 0.08 & 0.04 & 6.0 & 6.0 \\
\hline Misc. products & Misc. products & 0.02 & 0.01 & 16.3 & 9.5 \\
\hline Fuels and lighter & Fuels and lighter & 0.02 & 0.02 & 10.0 & 0.7 \\
\hline Total & & 9.45 & 6.38 & 31.5 & 6.9 \\
\hline
\end{tabular}

rest are largely branched and cyclic alkanes. The prominence of oxygenated IVOC emissions from VCPs is noteworthy, as SOA yields from these compounds have not historically been evaluated or included as SOA precursors in model chemical mechanisms (Qin et al., 2020). However, work has been undertaken in recent years to better understand these compounds (e.g., Wu and Johnson, 2017; Li and Cocker, 2018; Janechek et al., 2019; Charan et al., 2020). Overall, paints and coatings is the largest source of IVOC emissions ( $~ 760$ g per person per year; Fig. 3$)$, followed by printing inks $(\sim 350 \mathrm{~g}$ per person per year), cleaning products $(\sim 180 \mathrm{~g}$ per person per year $)$, and pesticides $(\sim 170 \mathrm{~g}$ per person per year). While paints and coatings emit more IVOCs by mass than all other PUCs, printing ink and pesticide emissions both feature greater proportions of IVOCs to their total emissions ( $\sim 44 \%$ and $\sim 28 \%$, respectively).

These results also highlight how emissions from each PUC and sub-PUC are uniquely driven by the mass of products used, organic composition, and use timescale. For example, the two largest sub-PUC sources are daily use products and general cleaners. Both are assigned a use timescale of $24 \mathrm{~h}$, but $40.6 \%$ of daily use products are organic while general cleaners are overwhelming composed of water (Table 2), and the annual mass usage of general cleaners is $\sim 3 \times$ higher than daily use products (Table 1). As a result, net emissions of general cleaners are within $10 \%$ of those from daily use products $(1.85$ and $2.04 \mathrm{~kg}$ per person per year, respectively). The emissions of short-use products, which is assigned a "minutes" use timescale, can further illustrate the importance of considering fate and transport. Under these use timescale assumptions, only high-volatility compounds (i.e., $\left.C^{*}>3 \times 10^{7} \mu \mathrm{g} \mathrm{m}^{-3}\right)$ are emitted and a majority $(\sim 97 \%)$ of its organics are retained (Table 3 ). Besides daily use products and general cleaners, all remaining sub-PUCs emit $\leq 1.14 \mathrm{~kg}$ per person per year, with six emitting less than $0.1 \mathrm{~kg}$ per person per year (Table 3). Generally, sub-PUCs with low emissions stem from minimal use (e.g., misc. products), short-use timescales (e.g., short-use products), or high control assumptions (e.g., oil and gas, fuels and lighter). 

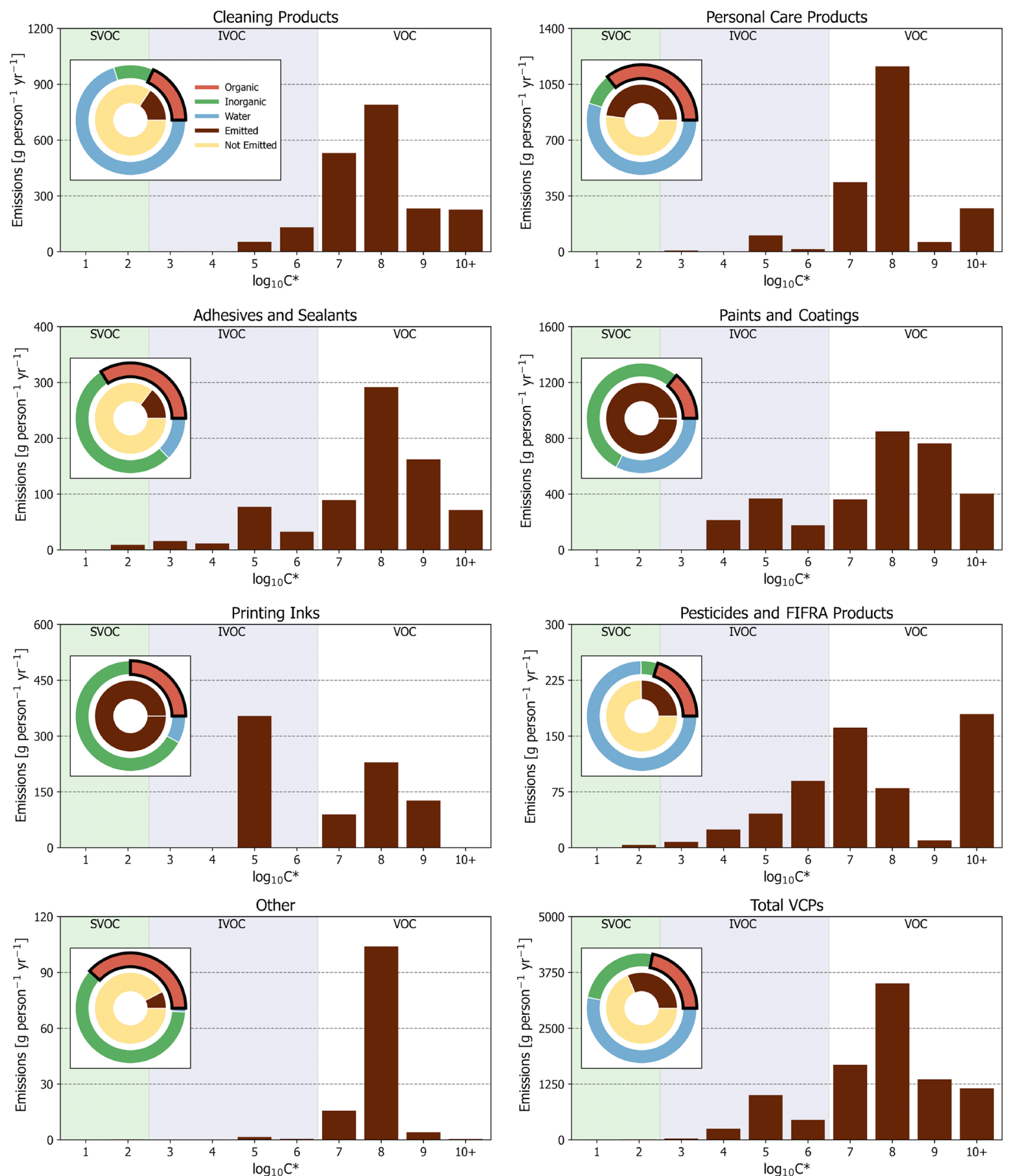

Figure 3. PUC and sector-wide volatility distribution of organic emissions. Other is a summation of dry cleaning, oil and gas, misc. products, and fuels and lighter. Pie charts are first-order product composition and organic emission proportions for PUCs and the complete sector. Note that the "organic" portion of all paints and coatings and printing inks pie charts is entirely composed of "evaporative organics" (see Table 2).

\subsection{Uncertainty analysis of national-level emission factors}

Uncertainty associated with product usage, proportion of evaporative organics, assumptions related to evaporation and use timescale, and post-use controls, where applicable, result in a total sector-wide emission uncertainty of $\pm 15 \%$ (Fig. 4; $9.5 \mathrm{~kg}$ per person per year, $95 \% \mathrm{CI}: 8.1-10.9)$. Interestingly, the interaction of evaporation and use timescales can result in a threshold effect, where small changes in either do not necessarily translate into changes in the magnitude of emissions for a given sub-PUC (Fig. S2). For many PUCs, such 
(a) Product Use Category Emissions
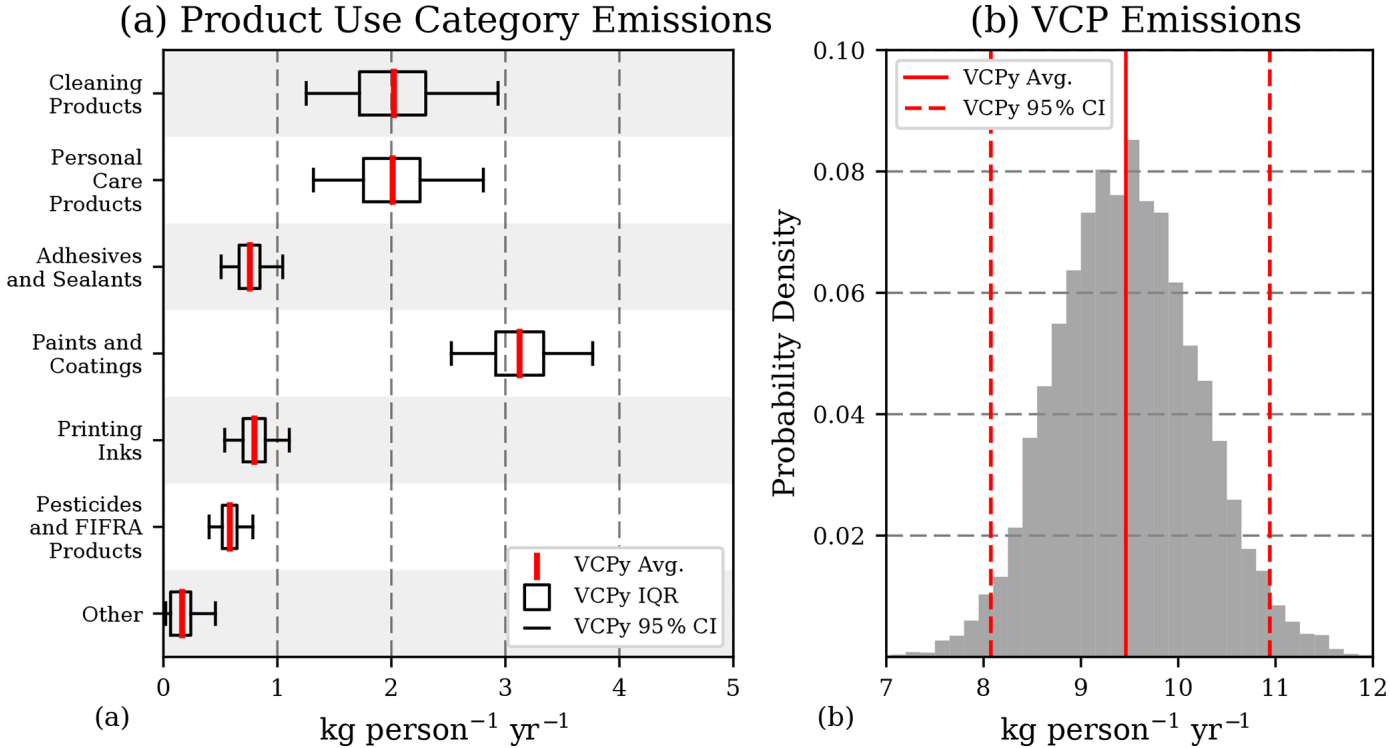

Figure 4. Monte Carlo sensitivity results for organic emissions. (a) Mean, interquartile range, and $95 \%$ confidence intervals for six PUCs and a combination of the remaining four (dry cleaning, oil and gas, misc. products, and fuels and lighter). (b) Probability distribution of sector-wide emission estimates. See Table S10 for a tabulation of this figure.

as paints and coatings, adhesives and sealants, and printing inks, the use timescale is sufficiently long (i.e., years) for all evaporative organics to evaporate, regardless of the uncertainty associated with the evaporation and use timescales. Under such conditions, only uncertainty in product usage and product composition affect uncertainty in the emission magnitude. As a result, these two variables are the largest drivers of uncertainty for the complete sector (Fig. S2). However, uncertainties associated with evaporation and use timescale assumptions can be important for certain sub-PUCs with moderate to low use timescales (see cleaning products in Fig. S2). For example, detergents and soaps is assigned a "minutes" use timescale, which results in a $0.12 \mathrm{~kg}$ per person per year emission factor (Table 3). If the use timescale for this subPUC was changed "hours," the emission factor would increase by a factor of 5 .

From a national emissions perspective, these Monte Carlo results contain several important results. First, as mentioned above, the largest drivers of uncertainty are associated with a sub-PUC's usage and composition, not assumptions related to fate and transport (i.e., evaporation and use timescales). Second, the most uncertain PUCs are cleaning products, personal care products, and paints and coatings, and their uncertainty generates a significant amount of emissions potential. The $95 \%$ confidence interval for all three span $>1.24 \mathrm{~kg}$ per person per year, which is equivalent to $>400 \mathrm{Gg}$ of organic emissions per year. Finally, the $95 \%$ confidence interval for the national-level emissions from the complete sector for 2016 is $2.6-3.5 \mathrm{Tg}(1.8-2.4 \mathrm{TgC})$, which is broadly consistent with the U.S. EPA's 2017 NEI $(2.8 \mathrm{Tg})$ and, largely due to differences in predicted evaporation, approximately half the emissions magnitude reported elsewhere (McDonald et al., 2018).

\subsection{State- and county-level emissions allocation}

The magnitude of VCP emissions varies substantially throughout the country, with the most populated states and counties featuring the highest ROC emissions (Fig. 5). California $(349 \mathrm{Gg})$, Texas $(247 \mathrm{Gg})$, and Florida $(173 \mathrm{Gg})$ are the largest state-level emitters and contribute $\sim 25 \%$ of all VCP emissions. In contrast, the 30 smallest state-level emitters (plus Washington, D.C.) together emit $\sim 780 \mathrm{Gg}$. At the county-level, Los Angeles County, Cook County (Chicago), and Harris County (Houston) are the largest emitters. However, after normalizing by population, these three counties all feature per capita emissions $(8.21,8.88$, and $8.76 \mathrm{~kg}$ per person per year, respectively) less than the national average (9.45 kg per person per year) due to less industrial activity.

National spatial variability in per capita emissions are largely driven by sub-PUCs tied to industrial and commercial activity (Fig. 5c). These sub-PUCs include allied paint products $(1.14 \mathrm{~kg}$ per person per year), industrial coatings ( $1.04 \mathrm{~kg}$ per person per year), printing inks $(0.80 \mathrm{~kg}$ per person per year), agricultural pesticides $(0.53 \mathrm{~kg}$ per person per year), and oil and gas ( $0.08 \mathrm{~kg}$ per person per year). The employment proxies for allied paint products, industrial coatings, and printing inks are usually consistent with the underlying population (Fig. S3), with peaks in California, Texas, Florida, New York, and the industrial Midwest. In contrast, emissions from agricultural pesticides and oil and gas drive the large per capita emissions in the Midwest 


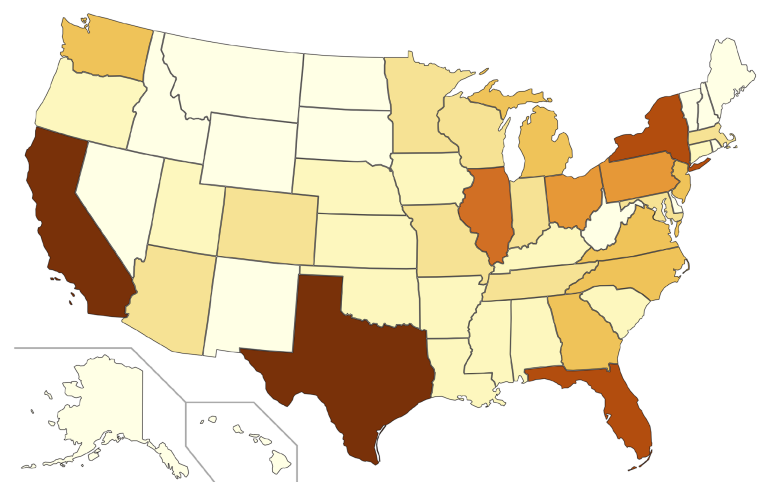

(a)

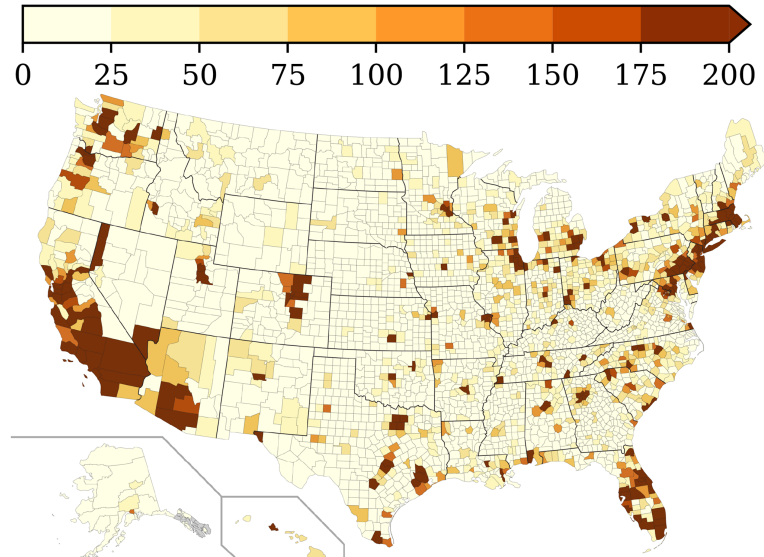

(b)
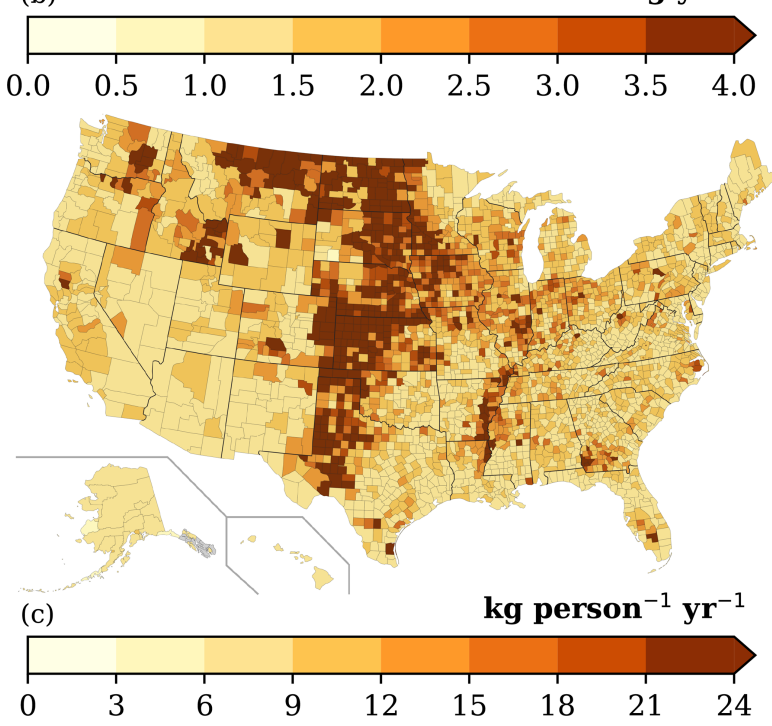

Figure 5. (a) State-level, (b) county-level, and (c) county-level per capita VCP emissions.

and Great Plains (Fig. 5c). Emissions from these two subPUCs are heavily concentrated in the central United States (Fig. S3), including North Dakota, South Dakota, Iowa, Nebraska, Kansas, and Oklahoma. Collectively, these states contain $<4.5 \%$ of the United States population but $24.1 \%$ and $17.5 \%$ of the agricultural pesticides and oil and gas VCP emissions, respectively. Both sub-PUCs also contribute to atypically high per capita emissions in other states, such as Texas, Colorado, Idaho, and Wyoming.

While national VCP emissions from the 2017 NEI and the VCPy inventory are broadly consistent, county-level and categorical estimates can differ substantially between the two (Fig. S4). For example, VCPy reports $>35 \%$ lower emissions for $5 \%$ of all counties and $>55 \%$ higher emissions for another $5 \%$ of all counties. When compared to the 2017 NEI, the states with the greatest emissions increases were Delaware, California, and Colorado, and the states with the greatest emissions decreases were North Dakota and South Dakota. There are also many spatial similarities between the two inventories. Both feature peaks in per capita emissions over the Midwest and Great Plains (Fig. S4), and approximately half of all county-level emissions in the VCPy inventory are within $15 \%$ of their value in the 2017 NEI. To compare the two inventories categorically, all product use categories are mapped to individual source classification codes (SCCs; Table S11). Categorically, VCPy reports higher emissions for personal care products $(150 \%)$ and paints and coatings $(25 \%)$, whereas pesticides $(-54 \%)$ and printing inks $(-13 \%)$ feature emission decreases. The VCPy inventory also includes marginal increases in cleaning products and adhesives and sealants emissions, while also quantifying solvent-borne emissions in oil and gas operations (included as "other" in Fig. S5).

\subsection{Evaluation of inventory using emission ratios}

Predicted per capita VCP emissions in Los Angeles County are $8.21 \mathrm{~kg}$ per person per year and consist of 250+ organic compounds. Observed emission ratios were available for 30 species (Table S7), including some of the most abundantly emitted (e.g., ethanol, acetone, isopropyl alcohol, toluene). In fact, of the 30 available emission ratios, 24 were for compounds that contributed more than $0.1 \%$ to total VCP emissions (Fig. 6), providing the opportunity to evaluate important markers. For most compounds, the VCPy estimate was well within a factor of 2 when compared to observations. Some important markers were marginally low biased (e.g., ethanol, isopropyl alcohol), while others were marginally high biased (e.g., acetone, methyl ethyl ketone, isobutane), illustrating the difficulty in precisely speciating organic emissions and uncertainties introduced by compositing. However, when considered as a whole, the complete VCPy inventory performs remarkably well with a correlation of 0.95 . In total, the observed emission ratio for all $30 \mathrm{com}$ pounds was $0.259 \mathrm{~g}(\mathrm{gCO})^{-1}$ and the inventory estimate is $0.226 \mathrm{~g}(\mathrm{~g} \mathrm{CO})^{-1}$, indicating a $13 \%$ low bias. In addition, the VCPy inventory shows a marked improvement over the 2017 NEI, which reports $3.28 \mathrm{~kg}$ per person per year of VCP emissions in Los Angeles County. For the 30 compounds considered here, the $2017 \mathrm{NEI}$ reports $0.143 \mathrm{~g}(\mathrm{~g} \mathrm{CO})^{-1}$, which is $45 \%$ lower than observations (Fig. S6). Most notably, the 


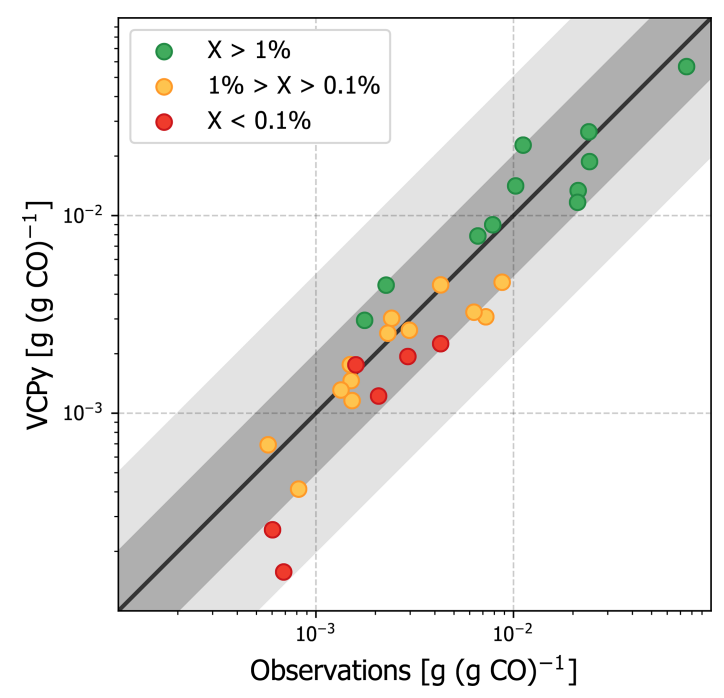

Figure 6. Evaluation of organic emission ratios in Los Angeles County using observed emission ratios from summer 2010. VCPy inventory ratios utilize VCPy predicted emissions for VCPs and the 2017 NEI for all other sources. The scatter point colors represent the relative abundance of each compound (represented as " $\mathrm{X}$ " in the figure legend) in the complete VCP sector. For example, all green points represent compounds that are $>1 \%$ of the total VCP emissions in Los Angeles County. The black line shows $1: 1$, the dark grey shading shows $2: 1$, and the light grey shading shows $5: 1$. Values available in Table S7.

emissions ratio of ethanol, acetone, isopropyl alcohol, and propane, all of which are emitted by VCPs in substantial quantities, were low by a factor of $2-3$.

While the residual, $13 \%$ low bias could suggest that additional organic emissions might be missing from the VCPy inventory, several other factors could explain discrepancies. First, emission ratios are equally sensitive to both organic and $\mathrm{CO}$ emissions. While $\mathrm{CO}$ appears to be represented and modeled well in current inventories (Lu et al., 2020), a marginal systematic bias in $\mathrm{CO}$ can affect the results presented here. For example, if the $\mathrm{CO}$ inventory were systematically biased high by $10 \%$, the bias in the VCPy inventory emission ratios would be nearly eliminated. Second, since emission ratios are not sector-specific but reflect total emissions, missing organic emissions might be from other sources. Mobile sources, especially gasoline exhaust, are rich in small $\left(\leq \mathrm{C}_{6}\right)$ hydrocarbons, including ethene, $n$-butane, $n$-pentane, isopentane, methylpentanes, propene, and methylhexanes (Gentner et al., 2013). Except for $n$-butane, none of the remaining compounds appreciably come from VCP sources, and all are biased low in the complete inventory (Fig. S6). Finally, while the ambient NMVOC to CO concentration ratio in Los Angeles has been consistent for several decades (McDonald et al., 2013), it is possible that trends for these two pollutants could have diverged in recent years.

\subsection{Effective $\mathrm{SOA}$ yields, $\mathrm{O}_{3} \mathrm{MIR}$, and air pollution potential}

Nationally, the effective SOA yield of the complete sector is $5.3 \%$ by mass (Table 4), and the most abundantly emitted SOA precursors are IVOC alkanes, aromatics, volatile methyl siloxanes, and fragrances. On a sub-PUC basis, the effective yield spans more than 2 orders of magnitude, with short-use products and printing inks featuring an effective yield of $0.05 \%$ and $14.8 \%$, respectively. For $\mathrm{O}_{3}$, the effective MIR of the complete sector is $1.6\left(\mathrm{~g} \mathrm{O}_{3}\right) \mathrm{g}^{-1}$ and, when compared to SOA yields, there is considerably less sub-PUC variability. While VCPs do emit aromatics and alkenes, both of which are photochemically reactive compound classes with high ozone potential, emissions are usually dominated by oxygenated compounds and alkanes, such as acetone, isopropyl alcohol, propane, and isobutane, which are minimally reactive. In fact, of the top 15 highest-emitting VCP compounds, 7 feature a MIR $<1.0\left(\mathrm{~g} \mathrm{O}_{3}\right) \mathrm{g}^{-1}$.

While a sub-PUC may be a large source of organic emissions, this does not necessarily translate to a high potential impact on $\mathrm{PM}_{2.5}$ and ozone. This is best highlighted by Industrial and architectural coatings. Together, these two subPUCs constitute $\sim 20 \%$ of all VCP emissions (Table 3), but only $\sim 10 \%$ of the total SOA potential due to their low effective yields (2.9\% and $1.9 \%$, respectively). Architectural coatings emissions feature significant quantities of Texanol $^{\mathrm{TM}}$ (a highly branched oxygenate) and small glycols, such as propylene and ethylene glycol. A $<1 \%$ and $0 \%$ SOA yield is assigned to Texanol ${ }^{\mathrm{TM}}$ and both glycols, respectively. However, it should be noted that this may be a lower bound, as Li et al. (2018) report moderate aerosol formation from propylene glycol. Similarly, printing inks contribute $\sim 8 \%$ of all VCP emissions, which is nearly $2.5 \times$ less than daily use products and general cleaners nationally (Table 3). However, printing ink emissions are dominated by IVOC alkanes (C12-C16 hydrocarbons, represented by $n$-tetradecane here) and aromatics, resulting in a high effective SOA yield $(14.8 \%)$. As a result, printing inks contribute significantly to the total SOA potential nationally (Fig. 7). Paints and coatings are nonetheless the dominant contributor to SOA potential, but this is more so due to the high emissions of the component sub-PUCs rather than their modest effective SOA yields $(1.9 \%-6.6 \%)$. Both general cleaners and daily use products also have moderate quantities of SOA precursors and high emissions, which translates to $17.5 \%$ and $13.3 \%$ of the national VCP SOA potential, respectively. Since the effective MIR of each sub-PUC is not highly variable, $\mathrm{O}_{3}$ potential is highly correlated with emissions magnitude. Overall, the three highest-emitting PUCs, paints and coatings, cleaning products, and personal care products, are also the highest contributors to $\mathrm{O}_{3}$ potential (Fig. 7).

These results also demonstrate how fate and transport assumptions can impact estimates of SOA production. For example, a prior study reported that both laundry detergent and 
Table 4. The national effective SOA yield and MIR for all sub-PUCs. These results are plotted in Fig. S7.

\begin{tabular}{|c|c|c|c|}
\hline $\begin{array}{l}\text { Product use categories } \\
\text { (PUCs) }\end{array}$ & $\begin{array}{l}\text { Sub-product use categories } \\
\text { (sub-PUCs) }\end{array}$ & $\begin{array}{r}\text { Effective SOA yield } \\
{[\%]}\end{array}$ & $\begin{array}{l}\text { Effective MIR } \\
{\left[\left(\mathrm{g} \mathrm{O}_{3}\right) \mathrm{g}^{-1}\right]}\end{array}$ \\
\hline \multirow[t]{2}{*}{ Cleaning products } & Detergents and soaps & 0.00 & 1.48 \\
\hline & General cleaners & 4.74 & 1.88 \\
\hline \multirow{2}{*}{ Personal care products } & Daily use products & 3.26 & 1.38 \\
\hline & Short-use products & 0.05 & 1.27 \\
\hline Adhesives and sealants & Adhesives and sealants & 6.19 & 1.51 \\
\hline \multirow[t]{4}{*}{ Paints and coatings } & Architectural coatings & 1.92 & 1.92 \\
\hline & Aerosol coatings & 3.26 & 1.66 \\
\hline & Allied Paint Products & 6.56 & 1.27 \\
\hline & Industrial Coatings & 2.94 & 1.71 \\
\hline Printing inks & Printing inks & 14.81 & 1.93 \\
\hline \multirow[t]{2}{*}{ Pesticides and FIFRA products } & FIFRA pesticides & 8.10 & 1.01 \\
\hline & Agricultural pesticides & 8.10 & 1.01 \\
\hline Dry cleaning & Dry cleaning & 3.47 & 1.13 \\
\hline Oil and gas & Oil and gas & 2.21 & 1.03 \\
\hline Misc. products & Misc. products & 1.94 & 2.26 \\
\hline Fuels and lighter & Fuels and lighter & 5.35 & 1.15 \\
\hline Total & & 5.29 & 1.58 \\
\hline
\end{tabular}

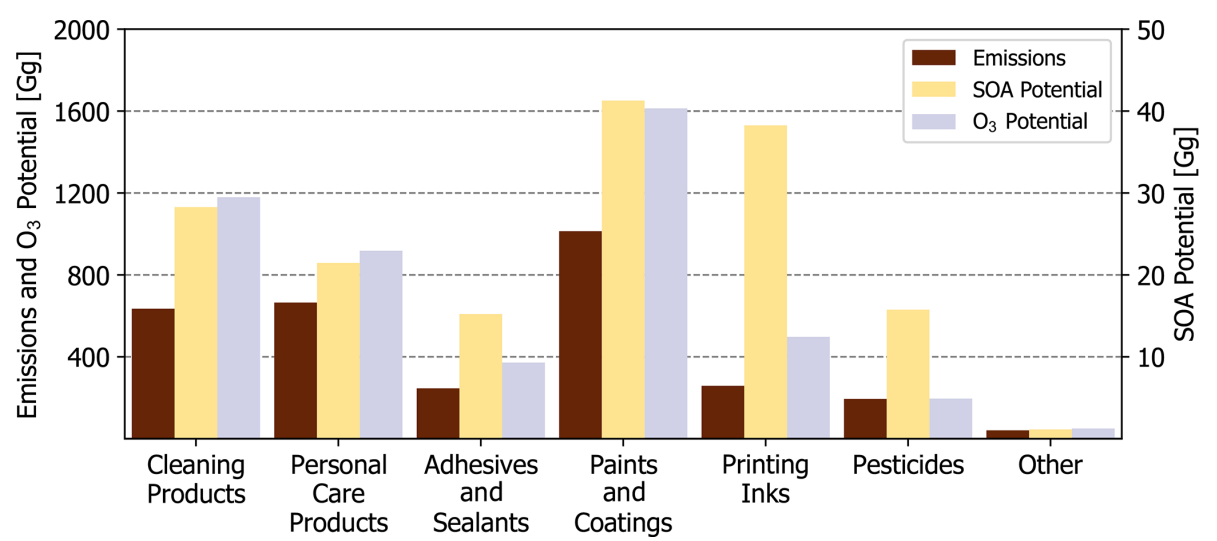

Figure 7. National-level emissions, SOA potential, and $\mathrm{O}_{3}$ potential by PUC. Other is a summation of dry cleaning, oil and gas, misc. products, and fuels and lighter.

a general-purpose spray cleaner can form appreciable quantities of SOA (Li et al., 2018). Here, the VCPy inventory reports an effective yield of $0.0 \%$ by mass of organic emitted for detergents and soaps and $4.7 \%$ for general cleaners (Table 4). While the organic content of both sub-PUCs, by mass, is $\geq 18 \%$ (Table 2), detergents and soaps feature a dramatically smaller use timescale (minutes vs. days). As a result, not only is the total mass of organic emissions from detergents and soaps smaller than general cleaners, but the collection of compounds that are emitted feature systematically smaller evaporation timescales. Such compounds are highly volatile (i.e., $C^{*}>1 \times 10^{8} \mu \mathrm{g} \mathrm{m}^{-3}$ ) and not SOA precursors. In contrast, general cleaners are assigned a longer use timescale, which provides time for lower volatility organics (i.e., IVOCs) to evaporate and subsequently contribute to the formation of SOA.

\subsection{Non-evaporative organic assumptions}

The composition and volatility distribution of the organics assumed to be non-evaporative, which is $\sim 60 \%$ of all organics (Fig. S8), is unidentified and assumed to 
be entirely non-volatile for the main analysis. However, there is evidence that a non-negligible portion of this mass may be SVOCs (semi-volatile organic compounds; $0.3 \mu \mathrm{g} \mathrm{m}^{-3}<C^{*}<300 \mu \mathrm{g} \mathrm{m}^{-3}$ ), which can evaporate on atmospherically relevant timescales (Khare and Gentner, 2018). SHEDS-HT, a near-field model used to prioritize human exposure to chemicals (Isaacs et al., 2014), reports that $>15 \%,>5 \%$, and $>2 \%$ of all organics found in residential personal care products, household products, and coatings, respectively, are composed of SVOCs (Qin et al., 2020). The treatment of non-evaporative organics and their potential emission can have a substantial impact on the modulation of SOA potential from VCPs. For example, if the assumption regarding evaporation of these organics is relaxed by assuming $1 \%$ of all non-evaporative organics eventually do evaporate, sector-wide emissions would increase by $0.18 \mathrm{~kg}$ per person per year (i.e., $<2 \%$ of the VCP emissions). Such a scenario is possible for products featuring long use timescales (e.g., paints, pesticides) if SVOCs are considered non-evaporative or if products featuring shorter use timescales (e.g., daily use products, cleaning products) are not fully sequestered. Since this increase in emissions is minor (i.e., $<2 \%$ ), there would be negligible impacts on the total emission magnitude and $\mathrm{O}_{3}$. However, these compounds, by definition feature low vapor pressures, which makes them prime SOA precursor candidates. If these compounds were permitted to form SOA with $100 \%$ efficiency, the effective yield from the complete sector would increase from $5.3 \%$ to $7.0 \%$ by mass (Fig. S8). Correspondingly, if $2 \%$ of all nonevaporative organics were assumed to evaporate with similar SOA formation assumptions, the effective yield from the complete sector would increase to $8.7 \%$ by mass.

\section{Additional uncertainties}

The current VCPy framework assumes all evaporated organics reach the ambient atmosphere, regardless of origin. However, VCP emissions occur both indoors and outdoors (Farmer et al., 2019; Nazaroff and Weschler, 2004; Singer et al., 2006a). In fact, the indoor concentration of prevalent VCP markers and secondary pollutants often exceeds outdoor concentrations (Farmer et al., 2019; Patel et al., 2020). For ambient air emissions, consideration of VCP emissions indoors is important if there is a gas-phase loss mechanism occurring at a scale that is comparable to typical indoor air exchange rates $\left(\sim 0.5 \mathrm{~h}^{-1}\right.$; Murray and Burmaster, 1995). Indeed, sorption of gas-phase organics (e.g., terpenes) into typical residential furnishing and dust has been shown to occur on relevant timescales (Singer et al., 2007, 2004; Weschler and Nazaroff, 2008). Organics emitted indoors can also react with oxidants, leading to the formation of lower-volatility organics that can form particulates (Nazaroff and Weschler, 2004; Singer et al., 2006b). These particulates can deposit before outdoor exhaust occurs due to the high surface-to- volume ratio of indoor settings (Abbatt and Wang, 2020; Farmer et al., 2019). Planned future VCPy functionality includes the incorporation of a two-box model to capture these possible termination mechanisms and distinguish between near-field and far-field exposure pathways.

In addition, the efficiency of post-use controls for several sub-PUCs can be highly uncertain and vary both in space and time. In particular, this includes oil and gas, which is assigned a post-use control based on average reported reinjection rates of produced water (Liden et al., 2018; Lyman et al., 2018), as well as industrial coatings and printing inks, which occur at facilities capable of add-on controls (U.S. Environmental Protection Agency, 2006a, b, 2007, 2008). Here, post-use controls are not assigned for industrial coatings or printing inks. As such, emissions from these sub-PUCs could feature localized high bias, depending on regional control requirements for facilities that use associated products. Similarly, the spatial allocation of nonpoint emissions features unique difficulties. For example, even if the allocation of nonpoint emissions was precisely matched to a quantifiable proxy, variation in the emission strength of individuals within that proxy (e.g., humans or employees) is often neglected ( $\mathrm{Li}$ et al., 2020).

\section{Conclusions}

VCPy is a new framework to model organic emissions from volatile chemical products throughout the United States, including spatial allocation to regional and local scales. In VCPy, product volatilization is a function of the characteristic evaporation timescale of individual components and the use timescale for product use categories. National per capita organic emissions from VCPs are $9.5 \mathrm{~kg}$ per person per year (6.4 $\mathrm{kgC}$ per person per year) for 2016 , which translates to $3.05 \mathrm{Tg}(2.06 \mathrm{Tg} \mathrm{C})$ for the U.S. Paints and coatings, personal care products, and cleaning products contribute the most to these emissions. When filtered to remove regulatory exempt organics, total emissions from VCPs are $2.6 \mathrm{Tg}$ of VOC and equal in magnitude to the sum of all mobile sources nationally, thus highlighting the growing importance of the VCP sector. Organic emissions featured substantial $(\sim 20 \%)$ contributions from IVOCs, which are likely SOA precursors. Of this $20 \%, 52 \%$ are oxygenated compounds, $30 \%$ are $n$ alkanes, and the rest are largely branched and cyclic alkanes. Nationally, the effective SOA yield and $\mathrm{O}_{3}$ MIR of VCPs, two metrics that facilitate an approximation of the potential air quality impacts, are $5.3 \%$ by mass and $1.58\left(\mathrm{~g} \mathrm{O}_{3}\right) \mathrm{g}^{-1}$, respectively. This effective SOA yield indicates VCPs are likely a significant source of SOA in urban environments (Qin et al., 2020).

Uncertainty associated with this framework was tested through Monte Carlo analysis. Notably, the dominant drivers of uncertainty were associated with estimated product usage and the composition of products, and not assumptions related 
to fate and transport. SOA formation from VCP emissions is especially sensitive to assumptions regarding evaporation of low-volatility species. If $1 \%$ of all non-evaporative organics eventually do evaporate, sector-wide emissions would increase by $0.18 \mathrm{~kg}$ per person per year, and the effective SOA yield from the complete sector could increase by $>1.5 \%$. The $95 \%$ confidence interval for the national-level emissions from the complete sector for 2016 is $2.61-3.53 \mathrm{Tg}$ (1.76$2.38 \mathrm{Tg} \mathrm{C}$ ). This is broadly consistent with the 2017 National Emission Inventory $(2.84 \mathrm{Tg}$ ) and half the emissions magnitude reported elsewhere (McDonald et al., 2018).

While the national-level emissions from the VCPy framework and the 2017 NEI are comparable, regional and localized differences can be significant. This is most clear when evaluating the VCPy inventory to published emission ratios. For Los Angeles County, the VCPy inventory performs well (normalized mean bias of $-13 \%$ with $r=0.95$ ) and is significantly improved over the reported 2017 NEI VCP emissions. Planned future work includes the adoption of variable emission settings (indoor vs. outdoor) to account for indoor loss mechanisms (e.g., gas-phase sorption to surfaces), revisited mapping of VCP emissions to common chemical mechanisms for ease of research use in the chemical transport modeling community, estimation of SOA and ozone formation from VCPs using a chemical transport model and VCPy emissions inputs, and understanding the evolution of VCP emissions over time.

Data availability. VCPy v1.0 is available from https://www.data.gov/ (last access: 11 March 2021) (https://doi.org/10.23719/1520157, Seltzer et al., 2021). All data presented in this manuscript can be retrieved and/or generated by downloading VCPy.v1.0. Guidance on using VCPy v1.0 can be requested by contacting the corresponding author.

Supplement. The supplement related to this article is available online at: https://doi.org/10.5194/acp-21-5079-2021-supplement.

Author contributions. KMS and HOTP designed the research scope. All authors participated in data curation and/or analysis. KMS and HOTP drafted the initial manuscript, and all authors contributed to subsequent drafts.

Competing interests. The authors declare that they have no conflict of interest.

Disclaimer. Although this work was contributed by research staff in the Environmental Protection Agency and has been reviewed and approved for publication, it does not reflect official policy of the EPA. The views expressed in this document are solely those of authors and do not necessarily reflect those of the Agency. EPA does not endorse any products or commercial services mentioned in this publication.

Acknowledgements. The authors would like to thank Janice Godfrey, Art Diem, Jennifer Snyder, Rich Mason, Caroline Farkas, Claudia Toro, Alison Eyth, Luke Valin, Mohammed Jaoui, Jim Szykman, Donna Schwede, Christian Hogrefe, Kristen Foley, Jesse Bash, Marc Houyoux, and Cindy Beeler at the U.S. EPA, Kyriacos Kyriacou and Jose Gomez at the California Air Resources Board, and David Cooley at Abt Associates for helpful discussions and/or data acquisition. Comments by Marc Houyoux (EPA), Jim Szykman (EPA), and two anonymous reviewers served to strengthen this paper.

Financial support. Karl Seltzer and Elyse Pennington have been supported by the Oak Ridge Institute for Science and Education (ORISE) Research Participation Program for the U.S. Environmental Protection Agency (EPA).

Review statement. This paper was edited by Kelley Barsanti and reviewed by two anonymous referees.

\section{References}

Abbatt, J. P. D. and Wang, C.: The atmospheric chemistry of indoor environments, Environ. Sci-Proc. Imp., 22, 25-48, https://doi.org/10.1039/c9em00386j, 2020.

Baker, K. R., Carlton, A. G., Kleindienst, T. E., Offenberg, J. H., Beaver, M. R., Gentner, D. R., Goldstein, A. H., Hayes, P. L., Jimenez, J. L., Gilman, J. B., de Gouw, J. A., Woody, M. C., Pye, H. O. T., Kelly, J. T., Lewandowski, M., Jaoui, M., Stevens, P. S., Brune, W. H., Lin, Y.-H., Rubitschun, C. L., and Surratt, J. D.: Gas and aerosol carbon in California: comparison of measurements and model predictions in Pasadena and Bakersfield, Atmos. Chem. Phys., 15, 5243-5258, https://doi.org/10.5194/acp15-5243-2015, 2015.

Bash, J. O., Baker, K. R., and Beaver, M. R.: Evaluation of improved land use and canopy representation in BEIS v3.61 with biogenic VOC measurements in California, Geosci. Model Dev., 9, 21912207, https://doi.org/10.5194/gmd-9-2191-2016, 2016.

Bishop, G. A. and Stedman, D. H.: A decade of on-road emissions measurements, Environ. Sci. Technol., 42, 1651-1656, https://doi.org/10.1021/es702413b, 2008.

Borbon, A., Gilman, J. B., Kuster, W. C., Grand, N., Chevaillier, S., Colomb, A., Dolgorouky, C., Gros, V., Lopez, M., Sarda-Esteve, R., Holloway, J., Stutz, J., Petetin, H., McKeen, S., Beekmann, M., Warneke, C., Parrish, D. D., and de Gouw, J. A.: Emission ratios of anthropogenic volatile organic compounds in northern mid-latitude megacities: Observations versus emission inventories in Los Angeles and Paris, J. Geophys. Res.-Atmos., 118, 2041-2057, https://doi.org/10.1002/jgrd.50059, 2013.

Burnett, R., Chen, H., Szyszkowicz, M., Fann, N., Hubbell, B., Pope, C. A., Apte, J. S., Brauer, M., Cohen, A., Weichenthal, S., Coggins, J., Di, Q., Brunekreef, B., Frostad, J., Lim, S. S., Kan, H. D., Walker, K. D., Thurston, G. D., Hayes, R. B., 
Lim, C. C., Turner, M. C., Jerrett, M., Krewski, D., Gapstur, S. M., Diver, W. R., Ostro, B., Goldberg, D., Crouse, D. L., Martin, R. V., Peters, P., Pinault, L., Tjepkema, M., Donkelaar, A., Villeneuve, P. J., Miller, A. B., Yin, P., Zhou, M. G., Wang, L. J., Janssen, N. A. H., Marra, M., Atkinson, R. W., Tsang, H., Thach, Q., Cannon, J. B., Allen, R. T., Hart, J. E., Laden, F., Cesaroni, G., Forastiere, F., Weinmayr, G., Jaensch, A., Nagel, G., Concin, H., and Spadaro, J. V.: Global estimates of mortality associated with long-term exposure to outdoor fine particulate matter, P. Natl. Acad. Sci. USA, 115, 9592-9597, https://doi.org/10.1073/pnas.1803222115, 2018.

California Air Resources Board (CARB): 2005 Architectural Coatings Survey - Final Report, 2007.

California Air Resources Board (CARB): 2010 Aerosol Coatings Survey Results, 2012.

California Air Resources Board (CARB): 2014 Architectural Coatings Survey - Draft Data Summary, 2014.

California Air Resources Board (CARB): ORGPROF - Organic chemical profiles for source categories, available at: https://ww2. arb.ca.gov/speciation-profiles-used-carb-modeling (last access: 28 August 2020), 2018.

California Air Resources Board (CARB): Final 2015 Consumer \& Commercial Product Survey Data Summaries, available at: https: //ww2.arb.ca.gov/sites/default/files/2020-08/2015_CP_Survey_ Summary_data_2019-12-09\%20\%28Autosaved\%29.xlsx (last access: 28 August 2020), 2019.

Cappa, C. D. and Wilson, K. R.: Multi-generation gas-phase oxidation, equilibrium partitioning, and the formation and evolution of secondary organic aerosol, Atmos. Chem. Phys., 12, 9505-9528, https://doi.org/10.5194/acp-12-9505-2012, 2012.

Carter, W. P. L.: Development of the SAPRC-07 chemical mechanism, Atmos. Environ., 44, 5324-5335, https://doi.org/10.1016/j.atmosenv.2010.01.026, 2010a.

Carter, W. P. L.: Updated Maximum Incremental Reactivity Scale and Hydrocarbon Bin Reactivities for Regulatory Applications, Prepared for California Air Resources Board Contract 07-339, available at: https://intra.engr.ucr.edu/ carter/SAPRC/ MIR10.pdf (last access: 11 March 2021), 2010b.

Carter, W. P. L.: Development of a database for chemical mechanism assignments for volatile organic emissions, J. Air Waste Manage., 65, 1171-1184, https://doi.org/10.1080/10962247.2015.1013646, 2015.

Chan, A. W. H., Kautzman, K. E., Chhabra, P. S., Surratt, J. D., Chan, M. N., Crounse, J. D., Kürten, A., Wennberg, P. O., Flagan, R. C., and Seinfeld, J. H.: Secondary organic aerosol formation from photooxidation of naphthalene and alkylnaphthalenes: implications for oxidation of intermediate volatility organic compounds (IVOCs), Atmos. Chem. Phys., 9, 3049-3060, https://doi.org/10.5194/acp-9-3049-2009, 2009.

Charan, S. M., Buenconsejo, R. S., and Seinfeld, J. H.: Secondary organic aerosol yields from the oxidation of benzyl alcohol, Atmos. Chem. Phys., 20, 13167-13190, https://doi.org/10.5194/acp-20-13167-2020, 2020.

de Gouw, J. A., Middlebrook, A. M., Warneke, C., Goldan, P. D., Kuster, W. C., Roberts, J. M., Fehsenfeld, F. C., Worsnop, D. R., Canagaratna, M. R., Pszenny, A. A. P., Keene, W. C., Marchewka, M., Bertman, S. B., and Bates, T. S.: Budget of organic carbon in a polluted atmosphere: Results from the New
England Air Quality Study in 2002, J. Geophys. Res.-Atmos., 110, D16305, https://doi.org/10.1029/2004jd005623, 2005.

de Gouw, J. A., Gilman, J. B., Kim, S. W., Lerner, B. M., IsaacmanVanWertz, G., McDonald, B. C., Warneke, C., Kuster, W. C., Lefer, B. L., Griffith, S. M., Dusanter, S., Stevens, P. S., and Stutz, J.: Chemistry of Volatile Organic Compounds in the Los Angeles basin: Nighttime Removal of Alkenes and Determination of Emission Ratios, J. Geophys. Res.-Atmos., 122, 1184311861, https://doi.org/10.1002/2017jd027459, 2017.

de Gouw, J. A., Gilman, J. B., Kim, S. W., Alvarez, S. L., Dusanter, S., Graus, M., Griffith, S. M., Isaacman-VanWertz, G., Kuster, W. C., Lefer, B. L., Lerner, B. M., McDonald, B. C., Rappengluck, B., Roberts, J. M., Stevens, P. S., Stutz, J., Thalman, R., Veres, P. R., Volkamer, R., Warneke, C., Washenfelder, R. A., and Young, C. J.: Chemistry of Volatile Organic Compounds in the Los Angeles Basin: Formation of Oxygenated Compounds and Determination of Emission Ratios, J. Geophys. Res.-Atmos., 123, 2298 2319, https://doi.org/10.1002/2017jd027976, 2018.

Di, Q., Wang, Y., Zanobetti, A., Wang, Y., Koutrakis, P., Choirat, C., Dominici, F., and Schwartz, J. D.: Air Pollution and Mortality in the Medicare Population, New Engl. J. Med., 376, 2513-2522, https://doi.org/10.1056/NEJMoa1702747, 2017.

Donahue, N. M., Kroll, J. H., Pandis, S. N., and Robinson, A. L.: A two-dimensional volatility basis set - Part 2: Diagnostics of organic-aerosol evolution, Atmos. Chem. Phys., 12, 615-634, https://doi.org/10.5194/acp-12-615-2012, 2012.

Ensberg, J. J., Hayes, P. L., Jimenez, J. L., Gilman, J. B., Kuster, W. C., de Gouw, J. A., Holloway, J. S., Gordon, T. D., Jathar, S., Robinson, A. L., and Seinfeld, J. H.: Emission factor ratios, SOA mass yields, and the impact of vehicular emissions on SOA formation, Atmos. Chem. Phys., 14, 2383-2397, https://doi.org/10.5194/acp-14-2383-2014, 2014.

Farmer, D. K., Vance, M. E., Abbatt, J. P. D., Abeleira, A., Alves, M. R., Arata, C., Boedicker, E., Bourne, S., Cardoso-Saldana, F., Corsi, R., DeCarlo, P. F., Goldstein, A. H., Grassian, V. H., Hildebrandt Ruiz, L., Jimenez, J. L., Kahan, T. F., Katz, E. F., Mattila, J. M., Nazaroff, W. W., Novoselac, A., O'Brien, R. E., Or, V. W., Patel, S., Sankhyan, S., Stevens, P. S., Tian, Y., Wade, M., Wang, C., Zhou, S., and Zhou, Y.: Overview of HOMEChem: House Observations of Microbial and Environmental Chemistry, Environ. Sci.-Proc. Imp., 21, 1280-1300, https://doi.org/10.1039/c9em00228f, 2019.

Gentner, D. R., Isaacman, G., Worton, D. R., Chan, A. W. H., Dallmann, T. R., Davis, L., Liu, S., Day, D. A., Russell, L. M., Wilson, K. R., Weber, R., Guha, A., Harley, R. A., and Goldstein, A. H.: Elucidating secondary organic aerosol from diesel and gasoline vehicles through detailed characterization of organic carbon emissions, P. Natl. Acad. Sci. USA, 109, 18318-18323, https://doi.org/10.1073/pnas.1212272109, 2012.

Gentner, D. R., Worton, D. R., Isaacman, G., Davis, L. C., Dallmann, T. R., Wood, E. C., Herndon, S. C., Goldstein, A. H., and Harley, R. A.: Chemical Composition of Gas-Phase Organic Carbon Emissions from Motor Vehicles and Implications for Ozone Production, Environ. Sci. Technol., 47, 11837-11848, https://doi.org/10.1021/es401470e, 2013.

Gentner, D. R., Jathar, S. H., Gordon, T. D., Bahreini, R., Day, D. A., El Haddad, I., Hayes, P. L., Pieber, S. M., Platt, S. M., de Gouw, J., Goldstein, A. H., Harley, R. A., Jimenez, J. L., Prevot, A. S. H., and Robinson, A. L.: Review of Urban Sec- 
ondary Organic Aerosol Formation from Gasoline and Diesel Motor Vehicle Emissions, Environ. Sci. Technol., 51, 10741093, https://doi.org/10.1021/acs.est.6b04509, 2017.

Heald, C. L. and Kroll, J. H.: The fuel of atmospheric chemistry: Toward a complete description of reactive organic carbon, Science Advances, 6, eaay8967, https://doi.org/10.1126/sciadv.aay8967, 2020.

Hildebrandt, L., Donahue, N. M., and Pandis, S. N.: High formation of secondary organic aerosol from the photooxidation of toluene, Atmos. Chem. Phys., 9, 2973-2986, https://doi.org/10.5194/acp-9-2973-2009, 2009.

Hodzic, A., Jimenez, J. L., Madronich, S., Canagaratna, M. R., DeCarlo, P. F., Kleinman, L., and Fast, J.: Modeling organic aerosols in a megacity: potential contribution of semi-volatile and intermediate volatility primary organic compounds to secondary organic aerosol formation, Atmos. Chem. Phys., 10, 5491-5514, https://doi.org/10.5194/acp-10-5491-2010, 2010.

Isaacs, K. K., Glen, W. G., Egeghy, P., Goldsmith, M. R., Smith, L., Vallero, D., Brooks, R., Grulke, C. M., and Ozkaynak, H.: SHEDS-HT: An Integrated Probabilistic Exposure Model for Prioritizing Exposures to Chemicals with Near-Field and Dietary Sources, Environ. Sci. Technol., 48, 12750-12759, https://doi.org/10.1021/es502513w, 2014.

Isaacs, K. K., Dionisio, K., Phillips, K., Bevington, C., Egeghy, P., and Price, P. S.: Establishing a system of consumer product use categories to support rapid modeling of human exposure, J. Expo. Sci. Env. Epid., 30, 171-183, https://doi.org/10.1038/s41370019-0187-5, 2020.

Janechek, N. J., Hansen, K. M., and Stanier, C. O.: Comprehensive atmospheric modeling of reactive cyclic siloxanes and their oxidation products, Atmos. Chem. Phys., 17, 8357-8370, https://doi.org/10.5194/acp-17-8357-2017, 2017.

Janechek, N. J., Marek, R. F., Bryngelson, N., Singh, A., Bullard, R. L., Brune, W. H., and Stanier, C. O.: Physical properties of secondary photochemical aerosol from $\mathrm{OH}$ oxidation of a cyclic siloxane, Atmos. Chem. Phys., 19, 1649-1664, https://doi.org/10.5194/acp-19-1649-2019, 2019.

Jathar, S. H., Woody, M., Pye, H. O. T., Baker, K. R., and Robinson, A. L.: Chemical transport model simulations of organic aerosol in southern California: model evaluation and gasoline and diesel source contributions, Atmos. Chem. Phys., 17, 43054318, https://doi.org/10.5194/acp-17-4305-2017, 2017.

Jimenez, J. L., Canagaratna, M. R., Donahue, N. M., Prevot, A. S. H., Zhang, Q., Kroll, J. H., DeCarlo, P. F., Allan, J. D., Coe, H., Ng, N. L., Aiken, A. C., Docherty, K. S., Ulbrich, I. M., Grieshop, A. P., Robinson, A. L., Duplissy, J., Smith, J. D., Wilson, K. R., Lanz, V. A., Hueglin, C., Sun, Y. L., Tian, J., Laaksonen, A., Raatikainen, T., Rautiainen, J., Vaattovaara, P., Ehn, M., Kulmala, M., Tomlinson, J. M., Collins, D. R., Cubison, M. J., Dunlea, E. J., Huffman, J. A., Onasch, T. B., Alfarra, M. R., Williams, P. I., Bower, K., Kondo, Y., Schneider, J., Drewnick, F., Borrmann, S., Weimer, S., Demerjian, K., Salcedo, D., Cottrell, L., Griffin, R., Takami, A., Miyoshi, T., Hatakeyama, S., Shimono, A., Sun, J. Y., Zhang, Y. M., Dzepina, K., Kimmel, J. R., Sueper, D., Jayne, J. T., Herndon, S. C., Trimborn, A. M., Williams, L. R., Wood, E. C., Middlebrook, A. M., Kolb, C. E., Baltensperger, U., and Worsnop, D. R.: Evolution of Organic Aerosols in the Atmosphere, Science, 326, 1525-1529, https://doi.org/10.1126/science.1180353, 2009.
Kazemiparkouhi, F., Eum, K. D., Wang, B. Y., Manjourides, J., and Suh, H. H.: Long-term ozone exposures and cause-specific mortality in a US Medicare cohort, J. Expo. Sci. Env. Epid., 30, 650658, https://doi.org/10.1038/s41370-019-0135-4, 2020.

Khare, P. and Gentner, D. R.: Considering the future of anthropogenic gas-phase organic compound emissions and the increasing influence of non-combustion sources on urban air quality, Atmos. Chem. Phys., 18, 5391-5413, https://doi.org/10.5194/acp18-5391-2018, 2018.

Li, L. J. and Cocker, D. R.: Molecular structure impacts on secondary organic aerosol formation from glycol ethers, Atmos. Environ., 180, 206-215, https://doi.org/10.1016/j.atmosenv.2017.12.025, 2018.

Li, W. H., Li, L. J., Chen, C. L., Kacarab, M., Peng, W. H., Price, D., Xu, J., and Cocker, D. R.: Potential of select intermediate-volatility organic compounds and consumer products for secondary organic aerosol and ozone formation under relevant urban conditions, Atmos. Environ., 178, 109-117, https://doi.org/10.1016/j.atmosenv.2017.12.019, 2018.

Li, Y., Rodier, C., Lea, J. D., Harvey, J., and Kleeman, M. J.: Improving spatial surrogates for area source emissions inventories in California, Atmos. Environ., 247, 117665, https://doi.org/10.1016/j.atmosenv.2020.117665, 2020.

Liden, T., Santos, I. C., Hildenbrand, Z. L., and Schug, K. A.: Treatment modalities for the reuse of produced waste from oil and gas development, Sci. Total Environ., 643, 107-118, https://doi.org/10.1016/j.scitotenv.2018.05.386, 2018.

Lu, Q., Zhao, Y., and Robinson, A. L.: Comprehensive organic emission profiles for gasoline, diesel, and gas-turbine engines including intermediate and semi-volatile organic compound emissions, Atmos. Chem. Phys., 18, 17637-17654, https://doi.org/10.5194/acp-18-17637-2018, 2018.

Lu, Q., Murphy, B. N., Qin, M., Adams, P. J., Zhao, Y., Pye, H. O. T., Efstathiou, C., Allen, C., and Robinson, A. L.: Simulation of organic aerosol formation during the CalNex study: updated mobile emissions and secondary organic aerosol parameterization for intermediate-volatility organic compounds, Atmos. Chem. Phys., 20, 4313-4332, https://doi.org/10.5194/acp20-4313-2020, 2020.

Lyman, S. N., Mansfield, M. L., Tran, H. N. Q., Evans, J. D., Jones, C., O’Neil, T., Bowers, R., Smith, A., and Keslar, C.: Emissions of organic compounds from produced water ponds I: Characteristics and speciation, Sci. Total Environ., 619, 896905, https://doi.org/10.1016/j.scitotenv.2017.11.161, 2018.

Mansfield, M. L., Tran, H. N. Q., Lyman, S. N., Bowers, R. L., Smith, A. P., and Keslar, C.: Emissions of organic compounds from produced water ponds III: Mass-transfer coefficients, composition-emission correlations, and contributions to regional emissions, Sci. Total Environ., 627, 860-868, https://doi.org/10.1016/j.scitotenv.2018.01.242, 2018.

Mansouri, K., Grulke, C. M., Judson, R. S., and Williams, A. J.: OPERA models for predicting physicochemical properties and environmental fate endpoints, J. Cheminformatics, 10, 10, https://doi.org/10.1186/s13321-018-0263-1, 2018.

McDonald, B. C., Gentner, D. R., Goldstein, A. H., and Harley, R. A.: Long-Term Trends in Motor Vehicle Emissions in US Urban Areas, Environ. Sci. Technol., 47, 10022-10031, https://doi.org/10.1021/es401034z, 2013. 
McDonald, B. C., Goldstein, A. H., and Harley, R. A.: Long-Term Trends in California Mobile Source Emissions and Ambient Concentrations of Black Carbon and Organic Aerosol, Environ. Sci. Technol., 49, 5178-5188, https://doi.org/10.1021/es505912b, 2015.

McDonald, B. C., de Gouw, J. A., Gilman, J. B., Jathar, S. H., Akherati, A., Cappa, C. D., Jimenez, J. L., Lee-Taylor, J., Hayes, P. L., McKeen, S. A., Cui, Y. Y., Kim, S. W., Gentner, D. R., Isaacman-VanWertz, G., Goldstein, A. H., Harley, R. A., Frost, G. J., Roberts, J. M., Ryerson, T. B., and Trainer, M.: Volatile chemical products emerging as largest petrochemical source of urban organic emissions, Science, 359, 760-764, https://doi.org/10.1126/science.aaq0524, 2018.

Mills, G., Sharps, K., Simpson, D., Pleijel, H., Frei, M., Burkey, K., Emberson, L., Uddling, J., Broberg, M., Feng, Z. Z., Kobayashi, K., and Agrawal, M.: Closing the global ozone yield gap: Quantification and cobenefits for multistress tolerance, Glob. Change Biol., 24, 4869-4893, https://doi.org/10.1111/gcb.14381, 2018.

Murphy, B. N., Woody, M. C., Jimenez, J. L., Carlton, A. M. G., Hayes, P. L., Liu, S., Ng, N. L., Russell, L. M., Setyan, A., Xu, L., Young, J., Zaveri, R. A., Zhang, Q., and Pye, H. O. T.: Semivolatile POA and parameterized total combustion SOA in CMAQv5.2: impacts on source strength and partitioning, Atmos. Chem. Phys., 17, 11107-11133, https://doi.org/10.5194/acp-1711107-2017, 2017.

Murray, D. M. and Burmaster, D. E.: Residential Air Exchange Rates in the United States: Empirical and Estimated Parametric Distributions by Season and Climatic Region, Risk Anal., 15, 459-465, https://doi.org/10.1111/j.15396924.1995.tb00338.x, 1995.

Nazaroff, W. W. and Weschler, C. J.: Cleaning products and air fresheners: exposure to primary and secondary air pollutants, Atmos. Environ., 38, 2841-2865, https://doi.org/10.1016/j.atmosenv.2004.02.040, 2004.

Ng, N. L., Kroll, J. H., Chan, A. W. H., Chhabra, P. S., Flagan, R. C., and Seinfeld, J. H.: Secondary organic aerosol formation from $m$-xylene, toluene, and benzene, Atmos. Chem. Phys., 7, 3909-3922, https://doi.org/10.5194/acp-7-3909-2007, 2007.

Ozone Transport Commission: OTC Model Regulations for Nitrogen Oxides $\left(\mathrm{NO}_{x}\right)$ and Photo-reactive Volatile Organic Compounds (VOCs), Technical Support Document, Ozone Transport Commission, Boston, MA, 2016.

Ozone Transport Commission: OTC Regulatory and Technical Guideline for Reduction of Ozone Precursor Emissions from Consumer Products - Phase V, Ozone Transport Commission, Boston, MA, 2018.

Patel, S., Sankhyan, S., Boedicker, E. K., DeCarlo, P. F., Farmer, D. K., Goldstein, A. H., Katz, E. F., Nazaroff, W. W., Tian, Y. L., Vanhanen, J., and Vance, M. E.: Indoor Particulate Matter during HOMEChem: Concentrations, Size Distributions, and Exposures, Environ. Sci. Technol., 54, 7107-7116, https://doi.org/10.1021/acs.est.0c00740, 2020.

Pollack, I. B., Ryerson, T. B., Trainer, M., Neuman, J. A., Roberts, J. M., and Parrish, D. D.: Trends in ozone, its precursors, and related secondary oxidation products in Los Angeles, California: A synthesis of measurements from 1960 to 2010, J. Geophys. Res.Atmos., 118, 5893-5911, https://doi.org/10.1002/jgrd.50472, 2013.
Presto, A. A., Miracolo, M. A., Donahue, N. M., and Robinson, A. L.: Secondary Organic Aerosol Formation from High-NOx Photo-Oxidation of Low Volatility Precursors: n-Alkanes, Environ. Sci. Technol., 44, 2029-2034, https://doi.org/10.1021/es903712r, 2010.

Qin, M. M., Murphy, B. N., Isaacs, K. K., McDonald, B. C., Lu, Q. Y., McKeen, S. A., Koval, L., Robinson, A. L., Efstathiou, C., Allen, C., and Pye, H. O. T.: Criteria pollutant impacts of volatile chemical products informed by near-field modelling, Nature Sustainability, 4, 129-137, https://doi.org/10.1038/s41893020-00614-1, 2020

Safieddine, S. A., Heald, C. L., and Henderson, B. H.: The global nonmethane reactive organic carbon budget: A modeling perspective, Geophys. Res. Lett., 44, 3897-3906, https://doi.org/10.1002/2017gl072602, 2017.

Sarwar, G., Olson, D. A., Corsi, R. L., and Weschler, C. J.: Indoor fine particles: The role of terpene emissions from consumer products, J. Air Waste Manage., 54, 367-377, https://doi.org/10.1080/10473289.2004.10470910, 2004.

Seltzer, K. M., Pennington, E., Rao, V., Murphy, B. N., Strum, M., Isaacs, K. K., and Pye, H. O. T.: Dataset for Reactive Organic Carbon Emissions from Volatile Chemical Products, EPA, https://doi.org/10.23719/1520157, 2021 (data available: https:// www.data.gov/, last access: 29 March 2021).

Shah, R. U., Coggon, M. M., Gkatzelis, G. I., McDonald, B. C., Tasoglou, A., Huber, H., Gilman, J., Warneke, C., Robinson, A. L., and Presto, A. A.: Urban Oxidation Flow Reactor Measurements Reveal Significant Secondary Organic Aerosol Contributions from Volatile Emissions of Emerging Importance, Environ. Sci. Technol., 54, 714-725, https://doi.org/10.1021/acs.est.9b06531, 2020.

Shin, H. M., McKone, T. E., and Bennett, D. H.: Contribution of low vapor pressure-volatile organic compounds (LVP-VOCs) from consumer products to ozone formation in urban atmospheres, Atmos Environ, 108, 98-106, https://doi.org/10.1016/j.atmosenv.2015.02.067, 2015.

Singer, B. C., Revzan, K. L., Hotchi, T., Hodgson, A. T., and Brown, N. J.: Sorption of organic gases in a furnished room, Atmos. Environ., 38, 2483-2494, 2004.

Singer, B. C., Coleman, B. K., Destaillats, H., Hodgson, A. T., Lunden, M. M., Weschler, C. J., and Nazaroff, W. W.: Indoor secondary pollutants from cleaning product and air freshener use in the presence of ozone, Atmos. Environ., 40, 6696-6710, $2006 \mathrm{a}$.

Singer, B. C., Destaillats, H., Hodgson, A. T., and Nazaroff, W. W.: Cleaning products and air fresheners: emissions and resulting concentrations of glycol ethers and terpenoids, Indoor Air, 16, 179-191, https://doi.org/10.1111/j.1600-0668.2005.00414.x, 2006b.

Singer, B. C., Hodgson, A. T., Hotchi, T., Ming, K. Y., Sextro, R. G., Wood, E. E., and Brown, N. J.: Sorption of organic gases in residential rooms, Atmos. Environ., 41, 3251-3265, 2007.

Stringfellow, W. T., Camarillo, M. K., Domen, J. K., and Shonkoff, S. B. C.: Comparison of chemical-use between hydraulic fracturing, acidizing, and routine oil and gas development, Plos One, 12 e0175344, https://doi.org/10.1371/journal.pone.0175344, 2017.

Strum, M. and Scheffe, R.: National review of ambient air toxics observations, J. Air Waste Manage., 66, 120-133, https://doi.org/10.1080/10962247.2015.1076538, 2016. 
The Freedonia Group: Solvents, Industry Study \#3429, The Freedonia Group, Cleveland, OH, 2016.

Tkacik, D. S., Presto, A. A., Donahue, N. M., and Robinson, A. L.: Secondary Organic Aerosol Formation from IntermediateVolatility Organic Compounds: Cyclic, Linear, and Branched Alkanes, Environ. Sci. Technol., 46, 8773-8781, 2012.

U. S. Bureau of Labor Statistics: Producer Price Index by Industry, retrieved from FRED, Federal Reserve Bank of St. Louis, available at: https://fred.stlouisfed.org/categories/31, last access: 21 August 2020.

U. S. Census Bureau: Paint and Allied Products - 2010, MA325F(10), available at: https://www.census.gov/data/tables/ time-series/econ/cir/ma325f.html (last access: 20 August 2020), 2011.

U. S. Census Bureau: Manufacturing and International Trade Report (MITR): 2016, Washington, D.C., USA, available at: https://www.census.gov/foreign-trade/Press-Release/MITR/ 2016/index.html (last access: 28 August 2020), 2016a.

U. S. Census Bureau: 2016 Annual Survey of Manufacturers (ASM), Washington, D.C., USA, available at: https://www.census.gov/data/tables/time-series/econ/asm/ 2013-2016-asm.html (last access: 11 March 2021), 2016b.

U. S. Census Bureau, Economy Wide Statistics Division: County Business Patterns, available at: https://www.census.gov/ programs-surveys/cbp/data/datasets.html (last access: 20 August 2020), 2018.

U. S. Census Bureau, Population Division: Annual Resident Population Estimates, Estimated Components of Resident Population Change, and Rates of the Components of Resident Population Change for States and Counties, available at: https://www.census.gov/data/datasets/time-series/demo/ popest/2010s-counties-total.html, last access: 21 August 2020.

U. S. Department of Transportation and the U. S. Department of Commerce: 2012 Commodity Flow Survey, EC12TCF-US, available at: https://www.census.gov/library/publications/2015/ econ/ec12tcf-us.html (last access: 21 August 2020), 2015.

U. S. Energy Information Administration: The Distribution of U. S. Oil and Natural Gas Wells by Production Rate, Washington, D.C., available at: https://www.eia.gov/petroleum/wells/ (last access: 21 August 2020), 2019.

U. S. Environmental Protection Agency: Study of Volatile Organic Compound Emissions from Consumer and Commercial Products, EPA 453/R-94-066, Research Triangle Park, NC, 1995.

U. S. Environmental Protection Agency: Control Techniques Guidelines for Offset Lithographic Printing and Letterpress Printing, EPA 453/R-06-002, Research Triangle Park, NC, available at: https://www3.epa.gov/airquality/ctg_act/200609_ voc_epa453_r-06-002_litho_letterpress_printing.pdf (last access: 20 August 2020), 2006a.

U. S. Environmental Protection Agency: Control Techniques Guidelines for Flexible Package Printing, EPA 453/R-06-003, Research Triangle Park, NC, available at: https://www3.epa.gov/airquality/ctg_act/200609_voc_epa453_ r-06-003_flexible_package_printing.pdf (last access: 20 August 2020), 2006b.

U. S. Environmental Protection Agency: Control Techniques Guidelines for Large Appliance Coatings, EPA 453/R-08-003, Research Triangle Park, NC, available at: https://www3.epa.gov/airquality/ctg_act/200709_voc_epa453_ r-07-004_lg_appliance_coating.pdf (last access: 20 August 2020), 2007.

U. S. Environmental Protection Agency: Control Techniques Guidelines for Automobile and Light-Duty Truck Assembly Coatings, EPA 453/R-08-006, Research Triangle Park, NC, available at: https://www3.epa.gov/airquality/ctg_act/200809_voc_ epa453_r-08-006_auto_ldtruck_assembly_coating.pdf (last access: 20 August 2020), 2008.

U. S. Environmental Protection Agency: Integrated Science Assessment for Particulate Matter, Office of Research and Development, Center for Public Health \& Environmental Assessment, RTP (Research Triangle Park), NC 2019a.

U. S. Environmental Protection Agency: Final Report, SPECIATE Version 5.0, Database Development Documentation, EPA/600/R-19/988, Research Triangle Park, NC, available at: https://www.epa.gov/air-emissions-modeling/ speciate-51-and-50-addendum-and-final-report (last access: 21 August 2020), 2019b.

U. S. Environmental Protection Agency: Integrated Science Assessment for Ozone and Related Photochemical Oxidants, Office of Research and Development, Center for Public Health \& Environmental Assessment, Research Triangle Park, NC, 2020a.

U. S. Environmental Protection Agency: 2017 National Emissions Inventory (NEI), Research Triangle Park, NC, available at: https://www.epa.gov/air-emissions-inventories/ 2017-national-emissions-inventory-nei-data (last access: 20 August 2020), 2020b.

Volkamer, R., Jimenez, J. L., San Martini, F., Dzepina, K., Zhang, Q., Salcedo, D., Molina, L. T., Worsnop, D. R., and Molina, M. J.: Secondary organic aerosol formation from anthropogenic air pollution: Rapid and higher than expected, Geophys. Res. Lett., 33, L17811, https://doi.org/10.1029/2006GL026899, 2006.

Warneke, C., McKeen, S. A., de Gouw, J. A., Goldan, P. D., Kuster, W. C., Holloway, J. S., Williams, E. J., Lerner, B. M., Parrish, D. D., Trainer, M., Fehsenfeld, F. C., Kato, S., Atlas, E. L., Baker, A., and Blake, D. R.: Determination of urban volatile organic compound emission ratios and comparison with an emissions database, J. Geophys. Res.-Atmos., 112, D10S47, https://doi.org/10.1029/2006jd007930, 2007.

Warneke, C., de Gouw, J. A., Holloway, J. S., Peischl, J., Ryerson, T. B., Atlas, E., Blake, D., Trainer, M., and Parrish, D. D.: Multiyear trends in volatile organic compounds in Los Angeles, California: Five decades of decreasing emissions, J. Geophys. Res.-Atmos., 117, D00V17, https://doi.org/10.1029/2012JD017899, 2012.

Weschler, C. J. and Nazaroff, W. W.: Semivolatile organic compounds in indoor environments, Atmos. Environ., 42, 90189040, 2008.

Williams, B. J., Goldstein, A. H., Kreisberg, N. M., Hering, S. V., Worsnop, D. R., Ulbrich, I. M., Docherty, K. S., and Jimenez, J. L.: Major components of atmospheric organic aerosol in southern California as determined by hourly measurements of source marker compounds, Atmos. Chem. Phys., 10, 11577-11603, https://doi.org/10.5194/acp-10-11577-2010, 2010.

Woody, M. C., Baker, K. R., Hayes, P. L., Jimenez, J. L., Koo, B., and Pye, H. O. T.: Understanding sources of organic aerosol during CalNex-2010 using the CMAQ-VBS, Atmos. Chem. Phys., 16, 4081-4100, https://doi.org/10.5194/acp16-4081-2016, 2016. 
Wu, Y. and Johnston, M. V.: Aerosol Formation from OH Oxidation of the Volatile Cyclic Methyl Siloxane (cVMS) Decamethylcyclopentasiloxane, Environ Sci Technol, 51, 44454451, https://doi.org/10.1021/acs.est.7b00655, 2017.

$\mathrm{Xu}$, L., Suresh, S., Guo, H., Weber, R. J., and Ng, N. L.: Aerosol characterization over the southeastern United States using high-resolution aerosol mass spectrometry: spatial and seasonal variation of aerosol composition and sources with a focus on organic nitrates, Atmos. Chem. Phys., 15, 7307-7336, https://doi.org/10.5194/acp-15-7307-2015, 2015.

Zhang, Q., Jimenez, J. L., Canagaratna, M. R., Allan, J. D., Coe, H., Ulbrich, I., Alfarra, M. R., Takami, A., Middlebrook, A. M., Sun, Y. L., Dzepina, K., Dunlea, E., Docherty, K., DeCarlo, P. F., Salcedo, D., Onasch, T., Jayne, J. T., Miyoshi, T., Shimono, A., Hatakeyama, S., Takegawa, N., Kondo, Y., Schneider, J., Drewnick, F., Borrmann, S., Weimer, S., Demerjian, K., Williams, P., Bower, K., Bahreini, R., Cottrell, L., Griffin, R. J., Rautiainen, J., Sun, J. Y., Zhang, Y. M., and Worsnop, D. R.: Ubiquity and dominance of oxygenated species in organic aerosols in anthropogenically-influenced Northern Hemisphere midlatitudes, Geophys. Res. Lett., 34, L13801, https://doi.org/10.1029/2007g1029979, 2007.
Zhao, Y. L., Hennigan, C. J., May, A. A., Tkacik, D. S., de Gouw, J. A., Gilman, J. B., Kuster, W. C., Borbon, A., and Robinson, A. L.: Intermediate-Volatility Organic Compounds: A Large Source of Secondary Organic Aerosol, Environ. Sci. Technol., 48, 13743-13750, https://doi.org/10.1021/es5035188, 2014.

Zhu, S. P., Mac Kinnon, M., Shaffer, B. P., Samuelsen, G. S., Brouwer, J., and Dabdub, D.: An uncertainty for clean air: Air quality modeling implications of underestimating VOC emissions in urban inventories, Atmos. Environ., 211, 256-267, https://doi.org/10.1016/j.atmosenv.2019.05.019, 2019. 